\title{
PRESIDENTIAL MANAGEMENT OF THE ADMINISTRATIVE STATE: THE NOT-SO-UNITARY EXECUTIVE
}

\author{
ROBERT V. PERCIVAL $\dagger$
}

"I'm a little puzzled. I'm being told that I can't just make a decision and have it promptly executed, that the Department can't just salute smartly and go execute whatever decision I make. Why is that?"

-President George H. W. Bush ${ }^{1}$

\section{INTRODUCTION}

The exigencies of the times powerfully influence conceptions of the proper scope of presidential power. In times of war or other national emergency, citizens expect strong leadership from the president in his role as commander-in-chief of the armed forces. In the wake of the September 11, 2001, terrorist attacks on the United States, presidential power is at its zenith as Congress and the public unite behind President George W. Bush's efforts to respond to the unprovoked slaughter of thousands of civilians on American soil.

Although the president's powers as commander-in-chief are expansive, there are constitutional bounds. Even in wartime presidents can overstep the limits of their constitutional authority in pursuit of seemingly important ends. President Truman's attempt during the

Copyright (C) 2001 by Robert V. Percival.

$\dagger$ Professor of Law, Robert Stanton Scholar, and Director, Environmental Law Program, University of Maryland School of Law. This Essay is based on a paper presented at the Duke Law Journal's Administrative Law Conference held at Duke University School of Law on March 5, 2001. The Duke University School of Law's Program in Public Law provided additional financial support for the 2001 conference. The author would like to thank Maryland law students Ann Oxenham, Kerri Roman, Marcia Tannian, and Patricia Teck for research assistance and Duke law student Christopher Evans for very helpful editorial suggestions.

1. David Kessler, A Question of Intent: A Great American Battle with a DeAdLY INDUSTRY 68 (2001) (quoting President George H. W. Bush at a White House meeting in January 1993 on regulations to implement the Nutrition Labeling and Education Act). 
Korean War to seize American steel mills to prevent a strike from crippling the economy was declared illegal by the Supreme Court in Youngstown Sheet \& Tube Co. v. Sawyer ${ }^{2}$ because it had not been authorized by Congress. This decision remains one of the Court's few pronouncements on the subject of constitutional limits on presidential power. Yet this topic will remain the subject of seemingly endless debate because of its continuing importance to understanding the structure of our government. Although this debate often acquires a distinctly partisan tinge, particularly when the White House and Congress are controlled by different political parties, ${ }^{3}$ it is vitally important, for the debate raises issues that go to the very heart of our constitutional scheme.

Much of the contemporary debate over presidential power has been spawned by continuing competition between Congress and the president for influence over administrative agencies. The enactment of numerous federal regulatory statutes to protect consumers, workers, the environment, the economy, and the civil rights of our citizenry has placed enormous authority in the hands of administrative agencies charged by law with responsibility for translating statutory directives into regulatory standards. From the dawn of the administrative state, the three branches of government have engaged in spirited competition to influence the policies adopted by agency officials. Given the vast scope of the duties invested in the federal bureaucracy, some scholars have argued that "the system of shared powers created by the constitution" has been transformed into "a system of shared influence over bureaucratic decisionmaking."

Some regulatory entities, such as the Federal Trade Commission, were created as independent agencies that are not subject to the same

2. 343 U.S. 579 (1952).

3. When control of the White House shifts from one party to another, it is fascinating to observe how quickly advocates can switch sides in articulating their visions of the proper scope of presidential authority. See, e.g., Jeanne Cummings, Bush Seeks to Buttress Defenses of the Executive Branch, Wall ST. J., Sept. 6, 2001, at A24 (discussing President George W. Bush's attempts to restore presidential powers by rebutting demands for information by the General Accounting Office and invoking executive privilege in response to subpoenas from House committees); Walter Dellinger, The Wrong Way to Oppose, WALL ST. J., Jan. 10, 2001, at A22 (cautioning Democrats against using the same tactics Republicans used in opposing President Clinton)

4. Peter L. Strauss, Legislative Theory and the Rule of Law: Some Comments on Rubin, 89 Colum. L. Rev. 427, 428 (1989) (quoting Congress: Structure And Policy 403 (Mathew D. McCubbins \& Terry Sullivan eds., 1987)). 
degree of presidential control as other executive agencies. ${ }^{5}$ Presidential efforts to influence decisions by nonindependent agencies have raised a fundamental legal question that goes to the heart of debates over presidential power: does the president have the legal authority to dictate regulatory decisions entrusted by statute to the heads of executive agencies? Most, though not all, federal regulatory statutes specify that regulations are to be promulgated by the heads of executive agencies. Because the president appoints (and can remove) these officials, he can have enormous influence over their policy decisions. But does this imply that the president has the power to dictate the substance of regulatory decisions that agencies are required by law to make?

The conventional wisdom is that the president does not have such authority. ${ }^{6}$ Thus, recent presidents' regulatory review programs have avoided express assertions of such authority. ${ }^{7}$ These regulatory review programs generally have been premised on the notion that the president lacks the power to displace decisionmaking authority granted by statute to agency officials. Although proponents of a "unitary executive" theory claim that the president's constitutional role as chief executive should give him unqualified executive power, including the authority to dictate agency decisions, ${ }^{8}$ review of the legal and

5. See Humphrey's Ex'r v. United States, 295 U.S. 602, 625-26 (1935) (holding that, although a president has unrestrained power to remove purely executive officers, such power does not extend to offices where Congress statutorily limited removal to certain causes).

6. See, e.g., Robert V. Percival, Rediscovering the Limits of the Regulatory Review Authority of the Office of Management and Budget, 17 ENVTL. L. REP. 10,017, 10,017 (1987) (discussing the Office of Management and Budget's alleged abuse of the regulatory process and the resulting debate about presidential authority over agency rulemaking); Richard H. Pildes \& Cass R. Sunstein, Reinventing the Regulatory State, 62 U. CHI. L. REV. 1, 25 (1995) (remarking that, even if an official risks losing his job over an action contrary to the president's will, the decision technically remains in the official's hands); Peter L. Strauss, The Place of Agencies in Government: Separation of Powers and the Fourth Branch, 84 COLUM. L. REV. 573, 649 (1984) (explaining that Congress can choose by statute to place the responsibility for decisions with the agency rather than the president); Peter L. Strauss \& Cass R. Sunstein, The Role of the President and OMB in Informal Rulemaking, 38 ADMIN. L. REV. 181, 201 (1986) (noting that the only real power a president has over appointed officials is that of removal, which is limited by political constraints).

7. The executive orders establishing regulatory review programs have been careful not to assert presidential authority to displace agency decisionmaking authority. See, e.g., Exec. Order No. 12,866 § 9, 3 C.F.R. 638, 649 (1994), reprinted in 5 U.S.C. $§ 601$ (2000) ("Nothing in this order shall be construed as displacing the agencies' authority or responsibilities, as authorized by law."); Exec. Order No. 12,291 § 3(f)(3), 3 C.F.R. 127, 130 (1982) ("Nothing in this subsection shall be construed as displacing the agencies' responsibilities delegated by law.").

8. See, e.g., Steven G. Calabresi, Some Normative Arguments for the Unitary Executive, 48 ARK. L. REV. 23, 29 (1994) (discussing how changed circumstances may impact society's 
policy considerations raised by this issue leads to a contrary conclusion.

This Essay argues that although the president's ability to remove agency heads gives him enormous power to influence their decisions, it does not give him the authority to dictate substantive decisions entrusted to them by law. When Congress enacts regulatory legislation vesting decisionmaking authority in agency heads, it generally envisions that decisions will be made by persons who possess expertise in the regulatory matters entrusted to them. Although the president's ability to appoint agency heads and to fire those who defy him makes public dissent by agency officials extremely rare, this dissent nonetheless can provide a highly valuable check on abuses of presidential power.

Part I of this Essay examines the scope of presidential power over decisionmaking by executive agencies. It considers what can be inferred from the sparse constitutional text and from the structure of government it erects, the most distinctive feature of which is the separation of powers. Part II then discusses how the first Congress, which included many of the Constitution's Framers, addressed questions concerning the president's authority over agencies when it enacted legislation establishing them. Part III reviews historical practices, including the history of presidential efforts to influence rulemaking and attempts by Congress and the judiciary to counter such influence. It examines congressional efforts to vest power in agency heads and to limit the president's authority to remove them. It also discusses presidential efforts to assert greater management authority over executive agencies, including the regulatory review programs employed by every president since Richard Nixon. Part IV then explores policy considerations that counsel against giving the president authority to dictate decisions entrusted by statute to executive officers.

notions about the appropriate scope of presidential power); Steven G. Calabresi \& Saikrishna B. Prakash, The President's Power to Execute the Laws, 104 YALE L.J. 541, 603-35 (1994) (arguing that the Framers intended to have a single person in charge of executing all federal laws). 


\section{PREsidential Powers AND The CONSTITUtion}

\section{A. The Textualist Argument}

The text of the Constitution says very little about the role of the president in managing administrative agencies. Article II, Section 1 of the Constitution states that "The executive Power shall be vested in the President of the United States of America." Although this provision does not specify what the executive power is, at least in the domestic arena, it surely reflects a considered decision to lodge ultimate authority for such power in a single individual. Following a vigorous debate over the dangers of accumulating too much power in a single person, delegates to the Constitutional Convention voted on June 4, 1787, by a margin of seven states to three, to establish the presidency, rejecting proposals to create some kind of executive council instead. ${ }^{10}$ By placing executive authority in a single person, the Framers sought to create a chief executive who would be energetic, effective, and accountable. ${ }^{11}$

Eschewing the use of a plural executive to prevent abuses of executive power, the Framers relied instead on a structural separation of executive, judicial, and legislative powers among three branches of government subject to an elaborate system of checks and balances. ${ }^{12}$ One important check on presidential power was the chief executive's need to rely on Congress to enact legislation establishing executive agencies. Article II, Section 2 of the Constitution gives the president the power of appointment to offices "which shall be established by law." ${ }^{13}$ Because Congress must enact laws to establish these offices, "the executive departments are creatures, not of the Constitution directly, but of Congressional statutes." ${ }^{14}$ The Constitution's description of Congress's legislative authority in Article I, Section 8's Neces-

9. U.S. CONST. art. II, § 1 .

10. See Theodore B. Olson, The Impetuous Vortex: Congressional Erosion of Presidential Authority, in The FetTered Presidency: Legal Constraints on the Executive BRANCH 225, 226 (L. Gordon Crovitz \& Jeremy A. Rabkin eds., 1989) (detailing the Framers' debate whether to create a unitary executive or a more diversified system).

11. See The Federalist No. 70, at 423 (Alexander Hamilton) (Clinton Rossiter ed., 1961) (outlining the advantages of a single executive).

12. Strauss, supra note 6, at 599 (arguing that separation of powers should be viewed more liberally as a separation of functions).

13. U.S. CONST. art. II, § 2, cl. 2.

14. James Hart, The Ordinance Making Powers of the President of THE United STATES 189 (1925). 
sary and Proper Clause suggests that the Framers envisioned that certain powers could be vested directly in executive departments or officers. This Clause provides Congress with the authority to enact laws "necessary and proper for carrying into Execution the foregoing Powers, and all other Powers vested by this Constitution in the Government of the United States, or in any Department or Officer thereof." ${ }^{15}$ Thus, under the Constitution, "the functions, powers, and duties of the heads of such departments are defined by Congress, in broad terms or minutely as to it seem best."16

The only other references in the Constitution to the president's executive authority are contained in Article II, Section 3's directive that the president "shall take Care that the Laws be faithfully executed"17 and in Article II, Section 2's grant of authority to the president to "require the Opinion, in writing, of the principal Officer in each of the executive Departments, upon any Subject relating to the Duties of their respective Offices." ${ }^{18}$ These provisions suggest that the president has some supervisory authority over the heads of executive agencies that may be useful in fulfilling his obligation to execute the laws.

The president's appointment and removal powers and the Framers' decision to vest executive authority in the president presumably give him considerable ability to influence decisions by executive officers. However, this does not provide a compelling case for concluding that the president may dictate decisions entrusted by Congress to the heads of executive agencies. Article II, Section 2's requirement that presidential appointments of executive officers be subject to the advice and consent of the Senate ${ }^{19}$ would have little meaning if the president simply could dictate the decisions such officers are required by law to make. By requiring Senate confirmation of the president's nominees to head cabinet agencies, the Constitution presumably envisions that these officers will have some degree of independence that makes it necessary for them to be acceptable not only to the president, but also to the Senate, one of the entities largely responsible for defining the powers, duties, and functions of their agencies. Moreover, if the president had authority to dictate the substance of agency

15. U.S. CONST. art I, § 8, cl. 18.

16. HART, supra note 14 , at 189.

17. U.S. CONST. art. II, $\S 3$.

18. Id. art. II, $\S 2$, cl. 1 .

19. Id. art. II, § 2, cl. 2. 
decisions, why would the Framers have found it necessary to expressly grant him the authority to demand opinions in writing from executive officers? Thus, from the text of the Constitution one could envision "a supervisory, perhaps even caretaker presidential role, in relationship to shadowy 'executive departments' from which opinions might be sought." 20

By failing to specify in any detail the role of executive agencies in the constitutional scheme they created, the Framers left considerable room for competition between the three branches of government for influence over the work of the bureaucracy. Some scholars believe that this creative tension is precisely what the Framers had hoped to produce to provide further checks and balances to prevent any single branch from acquiring too much power. ${ }^{21}$

\section{B. Separation of Powers}

The most distinctive feature of the governmental structure erected by the Constitution is its separation of the legislative, executive, and judicial functions into three branches of government. This separation of powers reflects a conscious effort to diffuse authority to prevent abuses of power. Inherent in this division of power is the notion that the president must respect statutory commands even when they require a result contrary to his own policy preferences. Thus, if there is a conflict between fidelity to a presidential directive and fidelity to a law enacted by Congress, agency heads must comply with the law. The Constitution instructs the president to exercise his executive authority in accordance with law. Article II, Section 3's directive that the president "shall take Care that the Laws be faithfully executed" 22 confirms that the president must comply with laws enacted by Congress. Article II, Section 1 of the Constitution vests the executive power in the president. But this executive power does not include the authority for the president unilaterally to change the law without legislative action by Congress. The clearest example of this is provided by the Court's decision in the Steel Seizure Case.

The Steel Seizure Case was spawned by President Truman's decision on April 8, 1952, to issue Executive Order 10,340, directing the secretary of commerce to seize eighty-eight private steel mills to pre-

\footnotetext{
20. Strauss, supra note 6, at 598 .

21. See id. at 604 (suggesting that mixed powers would preserve liberty)

22. U.S. CONST. art. II, § 3, cl. 3.

23. Youngstown Sheet \& Tube Co. v. Sawyer, 343 U.S. 579, 587-88 (1952).
} 
vent an impending nationwide strike from crippling steel production during the Korean War. ${ }^{24}$ In his biography of President Truman, David McCullough reports that prior to joining the Supreme Court, Justice Tom Clark, who had been Truman's attorney general, had advised Truman that the president had "inherent" power to prevent paralysis of the economy in the face of a national strike in a critical industry. ${ }^{25}$ McCullough also reports that the sitting Chief Justice, Fred Vinson, had advised Truman in confidence that he legally could seize the steel mills to prevent the strike. ${ }^{26}$

Truman's decision to seize the steel mills was condemned widely in the media. At a press conference Truman was asked whether he thought the president had inherent power to seize radio and television stations during a crisis. ${ }^{27}$ When he refused to rule out such a possibility, Truman compounded his public relations problems. ${ }^{28}$ A federal district judge quickly ruled the president's action illegal, noting that even a steel strike's "awful results[] would be less injurious to the public than the injury which would flow from a timorous judicial recognition that there is some basis for this claim to unlimited and unrestrained Executive power." 29

The Supreme Court promptly agreed to hear the case, and on June 2, 1952, it affirmed the district court's decision by a 6-3 vote with Chief Justice Vinson dissenting. ${ }^{30}$ The Court rejected the notion that presidential power to seize the steel mills could be implied from Article II's Vesting or Take Care Clauses or from the president's powers as commander-in-chief. In his opinion for the Court, Justice Black wrote that "[i]n the framework of our Constitution, the President's power to see that the laws are faithfully executed refutes the idea that he is to be a lawmaker." ${ }^{31}$ Black noted that the president's executive order did "not direct that a congressional policy be exe-

\footnotetext{
24. Id. at 583.

25. DAVID MCCullough, Truman 896-97 (1992).

26. Id. at 897 . Truman was in need of legal advice because he had fired his attorney general, J. Howard McGrath, just five days before the steel seizure. McGrath had fired a respected Republican lawyer, Newbold Morris, who had been hired by the Justice Department to take over an investigation of corruption at the Bureau of Internal Revenue. Id. at 894.

27. Id. at $899-900$.

28. Id. at 900 .

29. Youngstown Sheet \& Tube Co. v. Sawyer, 103 F. Supp. 569, 577 (D.D.C. 1952); MCCUllough, supra note 25, at 900.

30. Youngstown Sheet \& Tube Co. v. Sawyer, 343 U.S. 579, 582 (1952) (opinion of Black, J.); id. at 667 (Vinson, C.J., dissenting).

31. Id. at 587.
} 
cuted in a manner prescribed by Congress-it directs that a presidential policy be executed in a manner prescribed by the President." 32 While noting that Congress had the power "to adopt such public policies as those proclaimed by the order," Black concluded that "[ $\mathrm{t}] \mathrm{he}$ Constitution does not subject this lawmaking power of Congress to presidential or military supervision or control." ${ }^{33}$

The Steel Seizure Case confirms that the very notion of executive authority is founded in carrying out-executing - duties specified by law. If a federal regulatory statute entrusts certain decisionmaking responsibilities to the head of an executive agency, the president must respect that delegation. That does not mean that the president is prohibited from communicating with the agency head concerning his preferences for how the decision should be made, ${ }^{34}$ unless the statute requires that the decision be made through a formal adjudicatory process that bars ex parte contacts. ${ }^{35}$

For example, in Sierra Club v. Costle, the District of Columbia Circuit Court of Appeals found that there was no statutory prohibition on intraexecutive contacts during informal rulemaking, and it endorsed the desirability of presidential supervision of rulemaking. ${ }^{36}$ Writing for the court, Judge Wald observed that:

Of course, it is always possible that undisclosed Presidential prodding may direct an outcome that is factually based on the record, but different from the outcome that would have obtained in the absence of Presidential involvement. In such a case, it would be true that the political process did affect the outcome in a way the courts could not police. But we do not believe that Congress intended that the courts convert informal rulemaking into a rarified technocratic process, unaffected by political considerations or the presence of Presidential power. $^{37}$

Sierra Club v. Costle confirms that it is proper and desirable for the president to monitor the actions of agencies and to offer his views concerning what regulatory policies are appropriate. ${ }^{38}$ However, it

32. Id. at 588 .

33. Id.

34. Sierra Club v. Costle, 657 F.2d 298, 405-06 (D.C. Cir. 1981).

35. Portland Audubon Soc'y v. Or. Lands Coalition, 984 F.2d 1534, 1541 (9th Cir. 1993).

36. Costle, 657 F.2d at 404-08.

37. Id. at 408 .

38. It is important to remember that Sierra Club v. Costle refers only to decisions made through informal rulemaking. In Portland Audubon Society v. Oregon Lands Coalition, the Ninth Circuit held that the Administrative Procedure Act prohibited efforts by the White 
does not indicate that the president may dictate regulatory outcomes but, rather, only that if he is successful in influencing a decision it still must be based on factual support in the rulemaking record.

After all, any rule issued here with or without White House assistance must have the requisite factual support in the rulemaking record, and under this particular statute the Administrator may not base the rule in whole or in part on any "information or data" which is not in the record, no matter what the source. ${ }^{39}$

The decision also implicitly recognizes limits on the president's supervisory authority. Judge Wald's discussion of the relationship between the president and the Environmental Protection Agency (EPA) administrator appears to assume that the administrator retains ultimate responsibility for making the regulatory decisions. She noted that the administrator "needs to know the arguments" of White House staff, not that she must ultimately adopt them..$^{40}$ Judge Wald recognized that the president may be successful in "prodding" the administrator into adopting a different regulation than she originally contemplated, but she did not imply that the president has the authority to dictate the result. ${ }^{41}$

Principles of separation of powers continue to serve as a check on the exercise of presidential authority. During the administrations of both President Clinton and President George W. Bush, courts have applied the principles of the Steel Seizure Case to declare actions directed by executive orders to be illegal. In Chamber of Commerce $v$. Reich, ${ }^{42}$ the District of Columbia Circuit declared illegal an executive order issued by President Clinton ${ }^{43}$ that directed federal agencies not to do business with contractors who hire permanent replacements for striking employees. ${ }^{44}$ Noting that the National Labor Relations Act (NLRA) permits the hiring of permanent replacements for strikers,

House to influence a decision by members of an endangered species committee (also known as the "God Squad") because the committee hearings were adjudicatory hearings subject to the Administrative Procedure Act's prohibition on ex parte communications, including those from the president and his staff. 984 F.2d at 1536. The court reasoned that a contrary result would mean that the president "would effectively destroy the integrity of all federal agency adjudications." Id. at 1546.

39. Costle, 657 F.2d at 407-08 (emphasis omitted).

40. Id. at 406 .

41. Id. at 408 .

42. 74 F.3d 1322 (D.C. Cir. 1996).

43. Exec. Order No. 12,954, 3 C.F.R. 329 (1996).

44. 74 F.3d at 1324. 
the court reasoned that the Clinton executive order would upset the balance struck by Congress on an issue that "surely goes to the heart of United States labor relations policy." 45 Applying similar reasoning, a federal district court recently ruled illegal an executive order $^{46}$ issued by President George W. Bush that prohibited federal contractors from using project labor agreements. The court reasoned that the president lacked the authority under the Constitution and the Procurement Act to bar such agreements and that the executive order conflicted with the NLRA by prohibiting a practice that is legal under the Act. ${ }^{47}$

\section{The ORIGINALIST ARguMENT}

Further insight into the Framers' views concerning the relationship between the president and executive agencies can be obtained by examining the records of the first federal Congress. When the first Congress met in 1789 it faced the task of bringing to life the government the new Constitution had created. Members of this first Congress included many of the participants in the Constitutional Convention of 1787. One of the first orders of business for the new Congress was to establish executive agencies. On the House floor, Representative Elias Boudinot of New Jersey was the first to raise this matter: "If we take up the present constitution, we shall find it contemplates departments of an executive nature in aid of the President: it then remains for us to carry this intention into effect." 48 The first Congress pursued this objective by creating the departments of State, War, and Treasury, as well as the federal judiciary.

When the first Congress created executive agencies, it was concerned that the president would be able to exercise too much authority over them. The first department established by Congress was the Department of Foreign Affairs, which later became known as the State Department. ${ }^{49}$ During the congressional debate over establish-

45. Id. at 1337

46. Exec. Order No. 13,202, 66 Fed. Reg. 11,225 (Feb. 17, 2001), amended by 66 Fed. Reg. 18,717 (Apr. 6, 2001).

47. Bldg. \& Constr. Trades Dep't, AFL-CIO v. Allbaugh, No. 01-0902, 2001 WL 1381197, at $* 18, * 20$ (D.D.C. Nov. 7, 2001).

48. I CONG. REG. 1, 347 (May 19, 1789), available at http://mep.cla.sc.edu/dynaweb/MEP/ fc/@Generic_BookTextView/4872 (on file with the Duke Law Journal) (detailing congressional debate over the establishment of various executive branch departments).

49. After creating the Department of Foreign Affairs in July 1789, Congress rejected the idea of creating a Home Department that would perform a variety of functions not assigned to 
ing this department, a fundamental question of presidential authority was raised. While the president could appoint agency heads only with the advice and consent of the Senate, could he remove them without Senate approval? This spawned the first constitutional debate in the new Congress. ${ }^{50}$

The House of Representatives supported giving the president authority to remove executive officers without the consent of the Senate, but it was split over whether this should be stated explicitly in the legislation creating the department or simply inferred by implication from the Constitution. ${ }^{51}$ James Madison argued that because the Constitution made express provision for advice and consent on appointments, but was silent on the subject of removals, removals should fall within Article II's general grant of power to the president. ${ }^{52}$ William McClay, an opponent of giving the president unfettered powers of removal, claimed that Madison simply was trying to "pay his Court, to the President." 53

In Federalist No. 77, Alexander Hamilton argued that the consent of the Senate "would be necessary to displace as well as to appoint" federal officers. ${ }^{54} \mathrm{He}$ maintained that such a requirement would prevent an incoming president from disrupting the "steady administration" of government. ${ }^{55}$ However, Hamilton later changed his mind, causing considerable embarrassment to Representative William Smith of Maryland, who had quoted him during floor debate, only to be undercut by a note from Hamilton to the effect that Hamilton "was now convinced that the President alone should have the power of removal at pleasure."

In June 1789, the House approved giving the president the power to remove appointees without the consent of the Senate, im-

other departments, such as granting patents and copyrights and conducting the census. Margaret C.S. Christman, The First Federal Congress, 1789-1791, at 136 (1989). In September 1789, Congress assigned these duties to the new Department of Foreign Affairs, which was renamed the Department of State. Id.

50. Jack N. Rakove, Original Meanings: Politics and Ideas in the Making of THE CONSTITUTION 410 n.123 (1996).

51. JOHN C. Miller, THE FEDERALIST ERA: 1789-1801, at 30 (1960).

52. CHRISTMAN, supra note 49 , at 135.

53. Id.

54. The Federalist No. 77, at 459 (Alexander Hamilton) (Clinton Rossiter ed., 1961).

55. Id.

56. George C. Rogers, ed., The Letters from William Loughton Smith to Edward Rutledge, June 6, 1789 to April 28, 1794, 69 S.C. HIST. MAG. 1, 8 (1968). 
plying that this was the president's right under the Constitution. ${ }^{57}$ The vote was much closer in the Senate, which, after a fierce debate and considerable lobbying by members, split evenly when it voted in July. Vice President Adams broke the tie in favor of allowing the president unfettered powers of removal. ${ }^{58}$ Newspapers in his home state of Massachusetts suggested that Adams had been looking forward to his own presidency when he broke the tie in favor of greater presidential power. ${ }^{59}$

On September 2, 1789, President Washington signed legislation establishing the second federal executive department, the Department of the Treasury. ${ }^{60}$ Creation of this department had been a particular subject of controversy because it would control the new nation's finances. Fearful that it would lose the power of the purse, Congress considered creating a multimember Board of Treasury with powers carefully circumscribed by law. Citing the failures of the Continental Congress to manage financial matters effectively, James Madison argued forcefully in favor of creating an efficient agency headed by a single secretary. ${ }^{61}$ Fearful that the treasury secretary could be subject to too much presidential control, Congress directed him to submit his reports directly to Congress, rather than through the president, and it reserved the right to examine the agency's financial documents and to require information from the treasury secretary without presidential intervention. ${ }^{62}$ Alexander Hamilton, who had not pursued a seat in Congress in hopes of being appointed to head the Treasury, became the first treasury secretary. ${ }^{63}$

The new executive agencies created by the first Congress were a far cry from the vast bureaucracies that are a fixture of the modern administrative state. The number of nonmilitary officials working for the federal government in 1802 was 2597 ; in 1997 it was $1,872,000 .^{64}$ The State Department's Washington office consisted of only four

57. Mr. Benson, The Daily Advertiser, June 22, 1789, reprinted in 11 DocuMENTARY History of THE First Federal CONGRESS: Debates IN THE HOUSE OF REPRESENTATIVES: First SESSION, JUNE-SEPT. 1789, 902-04 (Charlene Bangs Bickford et al. eds., 1992).

58. RAKOVE, supra note 50, at 418 n.15.

59. CHRISTMAN, supra note 49, at 136.

60. Id. at 137.

61. IRVING BRANT, JAMES MADISON, FATHER OF THE CONSTITUTION, 1787-1800, at 258$61(1950)$.

62. MILLER, supra note 51, at 26-27.

63. CHRISTMAN, supra note 49 , at 142.

64. Bruce Ackerman, The New Separation of Powers, 113 HARV. L. REV. 633, 691 (2000). 
clerks, a messenger, and an office keeper, ${ }^{65}$ Secretary of State Thomas Jefferson spent most of his time reviewing patent applications. ${ }^{66}$ The most powerful agency, the Treasury Department, had thirty clerks and five officials below the level of secretary; it also was responsible for supervising nearly a thousand customhouse officials and internal revenue agents. ${ }^{67}$ Yet, even while acknowledging the president's broad executive powers, Congress entrusted agency heads with certain decisionmaking responsibilities, and it sought to preserve some independence for agency heads in their performance of those responsibilities. In light of the small size of agencies at the time, it can be inferred that Congress entrusted agency heads with certain decisionmaking responsibilities not because it was so necessary for the president to delegate executive authority, but because agency heads were thought to be capable of acquiring expertise relevant to their responsibilities.

\section{THE EXERCISE OF PRESIDENTIAL AUTHORITY: HISTORICAL PRACTICE}

\section{A. Congressional Efforts to Vest Power in Agency Heads}

In 1837 the Supreme Court endorsed a broad view of congressional power to impose duties on executive officers that would be exercised free of the president's control. In Kendall v. United States ${ }^{68}$ the Court granted a writ of mandamus requiring the postmaster general to pay money that Congress had ordered to be paid by special statute over the president's objections. In defense of his order that the money be withheld, the president invoked the Take Care Clause as a source of presidential authority to require the postmaster general not to perform a ministerial duty. ${ }^{69}$ But the Supreme Court rejected this view as an "alarming doctrine." 70 The Court distinguished between "certain political duties" imposed on executive officers "the discharge of which is under the direction of the President" and duties

65. MILLER, supra note 51, at 33.

66. CHRISTMAN, supra note 49 , at 142.

67. MiLleR, supra note 51, at 33.

68. 37 U.S. (12 Pet.) 524 (1837).

69. Id. at 539-41.

70. Id. at 610 . 
imposed on agency heads by Congress, which "are subject to the control of the law, and not to the direction of the President."

Not everyone agreed with early interpretations of presidential powers that approved of congressional vesting of decisionmaking responsibilities in agency heads. In 1855, Attorney General Cushing took the position that no department head could perform an official act against the will of the president, even in circumstances where Congress has delegated decisionmaking authority to the agency head.

Take now the converse form of legislation, that common or most ordinary style, in which an executive act is, by law, required to be performed by a given Head of Department. I think here the general rule to be as already stated, that the Head of Department is subject to the direction of the President. I hold that no Head of Department can lawfully perform an official act against the will of the President; and that will is by the Constitution to govern the performance of all such acts. $^{72}$

Cushing recognized that a "large proportion" of decisions by agencies are performed not by "any special direction" of the president. ${ }^{73}$ But he maintained that the president had the authority to direct agency decisions to prevent government from becoming a "parliamentary despotism" with a nominal chief executive lacking any real power. ${ }^{74}$

The historical practice clearly had been for cabinet secretaries to consult the president before they made important decisions. As President Benjamin Harrison wrote, the president "is responsible for all executive action, and almost everything that is out of the routine receives some attention from him." ${ }^{\text {75 }}$ President Harrison noted that "[r]outine matters proceed without the knowledge or interference of the President; but, if any matter of major importance arises the Secretary presents it for the consideration and advice of the President." ${ }^{, 76}$ In cases of disagreement between the president and agency heads, President Harrison noted that "there is a yielding of views, now on one side, now on the other; but it must, of course, follow that when the President has views that he feels cannot yield, those views must

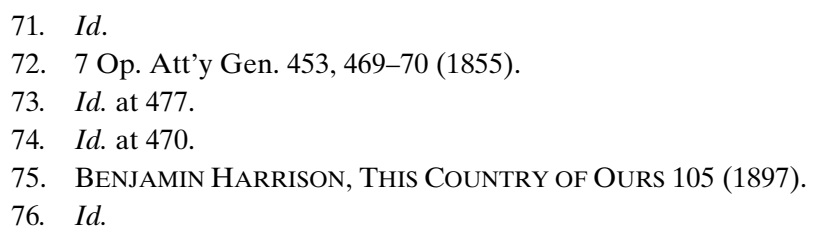


prevail, for the responsibility is his, both in a Constitutional and popular sense." farming-out of his Constitutional powers" to "eight Presidents," the agency heads he appointed. ${ }^{78}$

\section{B. The President's Removal Power}

The first Congress's decision not to attempt to condition the president's removal authority on the advice and consent of the Senate was only the beginning of the controversy over presidential removal powers. In 1833, when President Andrew Jackson removed the secretary of treasury for failure to carry out his policy toward the national bank, the Senate passed a resolution of censure. ${ }^{79}$ In defense of his action, President Jackson argued that he was simply exercising his authority under the Take Care Clause.$^{80}$ In 1867 , Congress passed the Tenure of Office Act, ${ }^{81}$ which required Senate consent to the removal of cabinet officers, ${ }^{82}$ over President Andrew Johnson's veto. ${ }^{83}$ This triggered the events that led to President Johnson's impeachment following his unsuccessful effort to remove Secretary of War Edwin M. Stanton. ${ }^{84}$ In 1872 and 1876, Congress adopted legislation requiring Senate consent before the postmaster general and various postmasters could be removed, though it repealed the Tenure of Office Act in 1887 following a confrontation with President Grover Cleveland. ${ }^{85}$

The Supreme Court's most significant pronouncements on the president's removal power came in Myers v. United States ${ }^{86}$ and Humphrey's Executor v. United States. ${ }^{87}$ Myers arose when President Wilson sought to remove a postmaster without the advice and consent of the Senate, as required by the 1876 legislation. ${ }^{88}$ After Myers

77. Id. at 106 .

78. Id. at 70 .

79. Louis Fisher, Constitutional Conflicts Between Congress And the PresiDENT 67 (1985).

80. Id.

81. Ch. 154,14 Stat. $430,430-32$ (1867).

82. Id. $\S 1$.

83. 14 Stat. 432 (noting that the president had vetoed the bill).

84. FISHER, supra note 79, at 69.

85. Id. at 70 .

86. 272 U.S. 52 (1926).

87. 295 U.S. 602 (1935).

88. Myers, 272 U.S. at $106-08$. 
sued, the Court upheld his removal by a 6-3 vote. ${ }^{89}$ In a broad interpretation of presidential power, former President and then-Chief Justice William Howard Taft, writing for the majority, proclaimed that the power to remove executive officers is "vest[ed] in the President alone." ${ }^{90}$ The Court's decision that the 1876 law requiring Senate advice and consent for removals was unconstitutional appeared to be a sweeping endorsement of presidential power. This perception changed significantly nine years later when the Court decided Humphrey's Executor v. United States.

Taft's sweeping interpretation of presidential power in Myers was severely undermined when the Court in Humphrey's Executor rejected President Franklin Roosevelt's effort to remove a member of the Federal Trade Commission (FTC) before the expiration of his seven-year term. The commissioner noted that Congress had adopted a statute permitting removals only for cause and that the president's only stated ground for removal was that the FTC member had been appointed by President Hoover. ${ }^{91}$ A unanimous Court found that Congress could require "cause" as a condition for removing an FTC commissioner. ${ }^{92}$ While the Court distinguished Myers on the ground that the FTC was an independent agency exercising quasi-legislative and quasi-judicial duties rather than an arm of the executive, ${ }^{93}$ the decision confirms the ability of Congress to restrict the president's removal authority over some executive officers. The Court noted that when Congress enacted the Federal Trade Commission Act it had intended to create a body "separate and apart from any existing department of the government-not subject to the orders of the President." 94

The Court's more contemporary decisions in Buckley v. Valeo ${ }^{95}$ and Bowsher v. Synar ${ }^{96}$ encouraged proponents of the "unitary executive" theory. Those decisions struck down on separation of powers grounds congressional appointment of members of the Federal Election Commission ${ }^{97}$ and the Graham-Rudman-Hollings Act, which

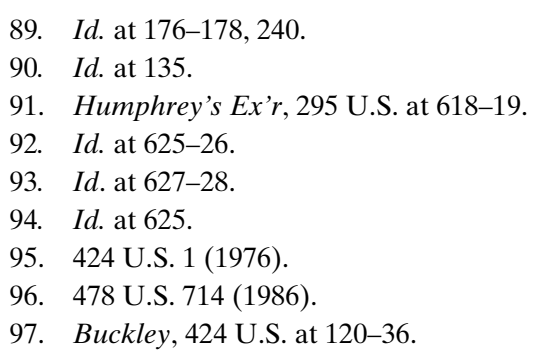


authorized the comptroller general, removable only by Congress, to review certain acts of the executive branch to enforce a balanced budget. ${ }^{98}$ However, the Court's subsequent decision in Morrison $v$. Olson, ${ }^{99}$ sustaining the appointment and "good cause" removal conditions for an independent counsel under the Ethics in Government Act, ${ }^{100}$ decisively rejected the notion that Article II's Vesting Clause requires that all executive officers serve at the pleasure of the president.

In Morrison, the Court, over Justice Scalia's dissent,${ }^{101}$ concluded that restrictions on the removal of an independent counsel did not impermissibly interfere with the president's ability to exercise executive power. ${ }^{102}$ In an opinion by Chief Justice Rehnquist, the Court criticized the unitary executive theory as a

rigid demarcation - a demarcation incapable of being altered by law in the slightest degree, and applicable to tens of thousands of holders of offices neither known nor foreseen by the framers-[that] depends upon an extrapolation from general constitutional language which we think is more than the text will bear. ${ }^{103}$

\section{Presidential Efforts to Manage the Executive Branch}

1. Presidential Management Before the Rise of the Administrative State. Even before the New Deal and the environmental and consumer protection legislation of the 1970s, many federal statutes gave the heads of executive agencies responsibility for regulatory decisions. For example, following the creation of the National Park Service in 1916, the secretary of the interior was directed by federal law to "make and publish such rules and regulations as he may deem necessary or proper for the use and management of the parks, monuments, and reservations under the jurisdiction of the National Park Service." ${ }^{104}$ Other legislation expressly granted broad powers to the president to set aside forest reserves and to create national monuments to

\footnotetext{
98. Bowsher, 478 U.S. at 734-36.

99. 487 U.S. 654 (1988).

100. Id. at 691.

101. Id. at 697 (Scalia, J., dissenting).

102. Id. at 695-96.

103. Id. at 690 n.29.

104. Act of Aug. 25, 1916, Pub. L. No. 64-235, § 3, 39 Stat. 535, 535 (establishing the National Park Service).
} 
preserve objects of "historic or scientific interest."105 These powers were used by Presidents Benjamin Harrison and Theodore Roosevelt to create the National Forest System and the first national monuments through executive orders. ${ }^{106}$

Most delegations of rulemaking authority had been made by Congress during wartime-initially the Civil War and later Congress's decision to give President Woodrow Wilson extraordinary powers that he could exercise with broad discretion during World War I. ${ }^{107}$ Although President Abraham Lincoln was the first to issue what was formally called an "executive order," the Congressional Research Service estimates that during the first seventy-two years of the republic-a period that spans the presidencies of George Washington to James Buchanan-presidents issued a total of 143 directives that now would be considered executive orders. ${ }^{108}$ As the following table indicates, the frequency with which executive orders were issued varied dramatically from one presidential administration to another. The dramatic increase in the use of executive orders during the administration of President Theodore Roosevelt (who issued executive orders nearly twelve times more frequently than his predecessor) reflects his aggressive use of presidential power to reshape national policy. Subsequent presidents made extensive use of executive orders as they mobilized the executive office to cope with wars and economic crises.

105. Antiquities Act of 1906, Pub. L. No. 59-209, § 2, 34 Stat. 225, 225.

106. Proclamation No. 17, 26 Stat. 1565 (1891) (creating National Forest System); Proclamation No. 658, 34 Stat. 3236 (1906) (creating the nation's first national monuments).

107. FISHER, supra note 79, at 295-96.

108. JOHN CONTRUBIS, CRS REPORT FOR CONGRESS: EXECUTIVE ORdERS AND Proclamations, at CRS-25, tbl. 1 (Mar. 9, 1999). 
PRESIDENTIAL ISSUANCE OF EXECUTIVE ORDERS ${ }^{109}$

\begin{tabular}{lccc}
\hline PRESIDENT & $\begin{array}{c}\text { Years in } \\
\text { Office }\end{array}$ & $\begin{array}{c}\text { Number of } \\
\text { Exec. Orders }\end{array}$ & $\begin{array}{c}\text { Exec. Orders } \\
\text { per Year }\end{array}$ \\
\hline Grover Cleveland & 4.0 & 71 & 17.8 \\
William McKinley & 4.5 & 51 & 11.3 \\
Theodore Roosevelt & 7.5 & 1,006 & 134.7 \\
William Taft & 4.0 & 698 & 174.5 \\
Woodrow Wilson & 8.0 & 1,791 & 223.9 \\
Warren Harding & 2.4 & 484 & 200.0 \\
Calvin Coolidge & 5.6 & 1,253 & 224.6 \\
Herbert Hoover & 4.0 & 1,011 & 252.8 \\
Franklin Roosevelt & 12.1 & 3,728 & 308.6 \\
Harry Truman & 7.8 & 896 & 115.2 \\
Dwight Eisenhower & 8.0 & 486 & 60.8 \\
John Kennedy & 2.8 & 214 & 75.4 \\
Lyndon Johnson & 5.2 & 324 & 62.8 \\
Richard Nixon & 5.6 & 346 & 62.3 \\
Gerald Ford & 2.5 & 169 & 69.0 \\
Jimmy Carter & 4.0 & 320 & 80.0 \\
Ronald Reagan & 8.0 & 381 & 47.6 \\
George H. W. Bush & 4.0 & 166 & 41.5 \\
William Clinton $^{110}$ & 8.0 & 364 & 45.5 \\
George W. Bush ${ }^{111}$ & 1.0 & 56 & 56.0 \\
\hline & & & \\
\hline & & 56 & \\
\hline
\end{tabular}

President Theodore Roosevelt transformed conceptions of presidential power by articulating a "stewardship" concept of presi-

109. Id. at CRS-25-26.

110. National Archives and Records Administration, Executive Orders Disposition Tables, Jan. 9, 1939-Jan. 16, 2002, at http://www.nara.gov/fedreg/eo.html (on file with the Duke Law Journal).

111. Id. 
dential administration ${ }^{112}$ and by making aggressive use of executive orders as a means of establishing federal policy. In addition to issuing executive orders, Roosevelt used the "bully pulpit" of the presidency in a wide variety of ways to influence policy. He lobbied Congress for new laws and for appropriations to promote new programs, appointed presidential commissions, convened conferences, required his personal approval for every transfer of federal lands to private interests, and cajoled executive officials to enforce existing laws. ${ }^{113}$

Roosevelt also sought to take control over communications between executive officials and Congress. In January 1902, he issued an executive order prohibiting executive officers from lobbying Congress except through the heads of their agencies. ${ }^{114}$ President William Howard Taft expanded Roosevelt's efforts to gain control over executive administration by broadening clearance requirements for executive communications to Congress and by establishing a Commission on Economy and Efficiency, which recommended the creation of a unified federal budget. ${ }^{115}$ When Taft announced that his administration would prepare such a budget, Congress responded angrily to what it perceived as an encroachment on its legislative prerogatives and adopted legislation prohibiting executive officials from preparing budget documents that were not specifically required by law. ${ }^{116}$

In 1919, Congress passed legislation giving the president authority to prepare a budget, but President Wilson vetoed the bill because it sought to restrict executive powers by making the newly established comptroller general an officer of Congress not removable by the president. ${ }^{117}$ In 1921, Congress enacted the Budget and Accounting Act, which created a Bureau of the Budget in the Department of the Treasury. ${ }^{118}$ In December 1921, the first director of the Bureau of the Budget, Charles M. Dawes, sought to expand its powers to require the heads of executive agencies to submit all legislative propos-

112. The Writings of Theodore Roosevelt 139 (William H. Harbaugh ed., 1967) (providing accounts of President Theodore Roosevelt's conservation policies for the nation's natural resources).

113. Id. at 147.

114. Kenneth R. Mayer, With the Stroke of a Pen: Executive Orders And PRESIDENTIAL POWER 115 (2001) (quoting Executive Order 163 from January 31, 1902).

115. Steven Skowronek, Building a New American State: The Expansion of NATIONAL ADMINISTRATIVE CAPACITIES, 1877-1920, at 187 (1982).

116. MAYER, supra note 114, at 117.

117. FISHER, supra note 79 , at 74 .

118. MAYER, supra note 114, at 113. 
als with financial consequences to the Bureau for clearance. ${ }^{119}$ This provoked vigorous opposition from agency heads, which resulted in Dawes backing off from enforcement of the requirement contained in Budget Circular No. 49, though it later was revived during the Coolidge administration and repeatedly expanded by President Franklin Roosevelt. ${ }^{120}$

During World War I, President Woodrow Wilson had made aggressive use of executive orders to increase the ability of the White House to manage the growing federal bureaucracy. Critics of presidential power complained that the executive branch was exercising too much legislative power in issuing rules, a practice then referred to as "ordinance making." An article in the Michigan Law Review in 1920 complained: "Few people are aware of the great extent to which public administration in the United States national government is controlled by means of administrative regulations or orders, in the nature of subordinate legislation." ${ }^{121}$ Even aside from "systematized and codified regulations, there is perhaps an even more extensive body of more specialized rules, orders, and instructions issued by the various departments, bureaus, commissions, and local agents, knowledge of which is often limited to the persons who have to apply them and to those whom they affect." 122

Writing in 1925, James Hart, a professor of political science, raised concerns about the delegation of legislative authority to executive agencies. While noting that the breadth of rulemaking authority exercised by executive agencies seemingly contradicted the Constitution's directive in Article I that "all legislative powers" be vested in Congress, he observed that the Supreme Court had studiously avoided confronting this conflict by referring to agency rulemaking as the exercise of "administrative" rather than "legislative" powers. ${ }^{123}$ This reflected in large part the practical reasons for rulemaking by executive agencies. "In thus refusing to call a spade a spade the Court has sought to allow needed flexibility in governmental ar-

119. Treasury Dep't Bureau of the Budget, Circular No. 49: Transmission to Congress of Estimates or Reports Involving Appropriations, Dec. 19, 1921, § 3, reprinted in CHARLES G. DAWES, THE FIRST YeAR OF THE BUdGET OF THE UNITED STATES 162 (1923).

120. MAYER, supra note 114, at 119-20.

121. John A. Fairlie, Administrative Legislation, 18 MICH. L. REV. 181, 181 (1920).

122. Id. at 183 .

123. HART, supra note 14 , at $17-18$.

124. Id. at 18 . 
rangements without admitting that Congress can devolve its constitutional powers upon the Executive."

Presidential power over the bureaucracy continued to expand with the enactment of the Reorganization Act of 1939, which gave the president power to reorganize the executive branch. ${ }^{126}$ The Act was a product of the recommendations of President Franklin Roosevelt's Brownlow Commission, which also spawned the creation of the Executive Office of the President. ${ }^{127}$ To increase the power of the Bureau of the Budget and to make it more accountable to the president, Roosevelt issued Executive Order 8248, which moved the Bureau into the Executive Office of the President. ${ }^{128}$ During World War II, the office expanded dramatically in size and power.

2. Presidential Management During the Nixon, Ford, and Carter Administrations: Increasing Activism. Beginning in the late 1960s, Congress established a series of regulatory programs to protect public health and safety, the environment, and consumer interests. ${ }^{129}$ These programs substantially increased the regulatory power of executive agencies, and they spawned the development of new mechanisms for presidential oversight of rulemaking by executive agencies. ${ }^{130}$ One of the most important presidential oversight mechanisms has been the creation of regulatory review processes, which were first instituted in the Nixon administration and continued in somewhat altered form by Presidents Ford and Carter.

President Nixon recognized the importance of asserting presidential influence over the actions of executive agencies that were acquiring more power with the new regulatory legislation. Shortly after taking office, he appointed the Ash Council on Executive Reorganization to make recommendations for reorganizing the executive

125. Id.

126. Reorganization Act of 1939, Pub. L. No. 76-19, 53 Stat. 561 (1939).

127. Peri E. Arnold, Making the Managerial Presidency: Comprehensive REORGANIZATION PLANNING, 1905-1996, at 103 (2d ed. 1998).

128. Exec. Order No. 8248, 3 C.F.R. 576, 576 (1938-1943) ("[e]stablishing the divisions of the Executive Office of the President and defining their functions and duties").

129. See Robert V. Percival et al., Environmental Regulation: Law, Science, AND POLICY 104-09 (3d ed. 2000) (describing the development of major federal environmental legislation starting in the 1960s).

130. For a history of presidential oversight of rulemaking covering the period from 1970 through 1990, see generally Robert V. Percival, Checks Without Balance: Executive Office Oversight of the Environmental Protection Agency, 54 LAW \& CONTEMP. PROBS. 127, 128-55 (Autumn 1991). 
branch. ${ }^{131}$ Based on the Ash Council's recommendations, in July 1970 President Nixon issued Executive Order 11,541, which created the Office of Management and Budget (OMB) and gave it the authority that previously had been exercised by the Bureau of the Budget. ${ }^{132}$ The Nixon administration also substantially increased the size of the White House staff and created the Domestic Council, which assumed responsibility for coordinating the actions of executive agencies. ${ }^{133}$

To allay the corporate community's fears of the consequences of the new federal regulatory legislation, President Nixon on April 9, 1970, issued an executive order creating the National Industrial Pollution Control Council (NIPCC).$^{134}$ NIPCC consisted of sixty-three top corporate executives appointed by Commerce Secretary Maurice Stans who met in secret with federal officials to air complaints about impending regulatory actions. ${ }^{135}$

As part of the reorganization of the executive branch undertaken in response to the recommendations of the Ash Council, President Nixon created the EPA by executive order. ${ }^{136}$ The EPA went into operation on December 2, 1970. Nixon also proposed creating four new superagencies to replace existing cabinet offices. ${ }^{137}$ However, he did not include the EPA in this proposal because of the importance of keeping the EPA's regulatory functions independent from the programs of the other cabinet offices. ${ }^{138}$ To provide a mechanism for exerting presidential influence on environmental and workplace safety regulations, President Nixon established the "Quality of Life" review program. This program required the EPA and the Occupational Safety and Health Administration (OSHA) to submit proposals for significant environmental and occupational safety

131. MAYER, supra note 114 , at 123.

132. Exec. Order No. 11,541, 3 C.F.R. 939, 939 (1966-1970), reprinted in 31 U.S.C. $\S 501$ (1994) ("[p]rescribing the duties of the Office of Management and Budget and the Domestic Council in the Executive Office of the President").

133. Elena Kagan, Presidential Administration, 114 HARV. L. REV. 2245, 2276 (2001).

134. Exec. Order No. 11,523, 3 C.F.R. 915, 915 (1966-1970), reprinted in 42 U.S.C. $\$ 4321$ (1994) ("[e]stablishing the National Industrial Pollution Control Council").

135. The stated purpose of the NIPCC was to "allow businessmen to communicate regularly with the President, the Council on Environmental Quality, and other governmental officials and private organizations" with respect to regulatory initiatives. Percival, supra note 130, at 130 .

136. Reorg. Plan No. 3 of 1970, 3 C.F.R. 1072 (1966-1970), reprinted in 42 U.S.C. $§ 4321$ (1994), and in 84 Stat. 2086 (1970) (establishing the Environmental Protection Agency).

137. Percival, supra note 130 , at 133.

138. Id. 
regulations to OMB so that they could be circulated to other agencies for review and comment before they were issued. ${ }^{139}$ This review process produced several heated battles among the EPA, the Department of Commerce, and OMB over regulations being developed by the environmental agency.

President Ford continued the Quality of Life review program, though his administration was less involved in efforts to influence regulatory decisions than the Nixon administration had been. In November 1974, President Ford issued Executive Order 11,821, which required agencies to prepare inflation impact statements before promulgating major regulations. ${ }^{140}$ The newly created Council on Wage and Price Stability was given responsibility for reviewing proposed rules for their inflationary impact, a process that took place on the rulemaking record during the normal public comment period for proposed regulations..$^{141}$ Unlike the Nixon administration's regulatory review program, which had focused exclusively on environmental regulations, the Ford administration's program concentrated primarily on economic regulations such as those issued by the Interstate Commerce Commission and the Civil Aeronautics Board. ${ }^{142}$

President Carter's regulatory review program was established by Executive Order 12,044, issued on March 23, 1978. ${ }^{143}$ It required executive agencies to prepare a "regulatory analysis" for all proposed rules likely to have an annual economic impact of $\$ 100$ million or more. ${ }^{144}$ These analyses, which were to include an assessment of the economic consequences of the proposed regulation and an evaluation of alternatives to it, were reviewed by an interagency committee called the Regulatory Analysis Review Group (RARG) ${ }^{145}$ RARG was composed of representatives from seventeen agencies and chaired by the chairman of the Council of Economic Advisers. ${ }^{146}$

139. Id. at $133-34$.

140. Exec. Order No. 11,821 § 1, 3 C.F.R. 926, 926 (1971-1975), reprinted in 12 U.S.C. $\S$ 1904 (1994) (ordering the preparation of "Inflation Impact Statements").

141. Percival, supra note 130, at 139-40.

142. Id. at 140.

143. Exec. Order No. 12,044 pmbl., 3 C.F.R. 152, 152 (1979), reprinted in 5 U.S.C. $§ 553$ (1994) (directing the agencies of the executive branch "to adopt procedures to improve existing and future regulations").

144. Id. § 3,3 C.F.R. at 154 .

145. Christopher C. DeMuth, Constraining Regulatory Costs-Part One: The White House Review Programs, REG.: AEI J. ON GOV'T \& SOC'Y, Jan.-Feb. 1980, at 16.

146. Robert E. Litan \& William D. Nordhaus, Reforming Federal Regulation 69 n.18 (1983). 
During the waning days of the Carter administration in 1980, Congress enacted the Regulatory Flexibility Act and the Paperwork Reduction Act. The Regulatory Flexibility Act requires agencies to perform detailed analyses of alternatives to regulations likely to have a disproportionate impact on small businesses. ${ }^{147}$ This legislation had little significance for agencies until Congress made compliance with its provisions subject to judicial review by adopting the Small Business Regulatory Enforcement Fairness Act in $1996 .{ }^{148}$ The Paperwork Reduction Act broadened OMB's authority to prevent agencies from imposing unnecessary paperwork burdens on the public by requiring OMB clearance for all agency proposals to collect information. ${ }^{149}$ It also created OMB's Office of Information and Regulatory Affairs (OIRA), ${ }^{150}$ the OMB office now responsible for conducting regulatory reviews for the Executive Office of the President.

The executive orders creating the regulatory review programs established by Presidents Nixon, Ford, Carter, Reagan, and George H. W. Bush were careful not to assert presidential authority to dictate agency decisions. As noted above, the Nixon, Ford, and Carter programs consisted largely of interagency review procedures that did not purport to allow the Executive Office of the President to block or to modify agency regulatory actions. ${ }^{151}$

During the Nixon administration, OMB vigorously opposed certain regulatory initiatives, but it conceded that the agencies "would have final say on whether to adopt a specific regulation." ${ }^{\text {152 }}$ In 1972, there were allegations that OMB was making regulatory decisions for the EPA. Denying these charges, EPA Administrator William Ruckelshaus stated that "if they were, I would be breaking the law, and I would not function as Administrator of this Agency if I let them do so." ${ }^{, 53}$ However, OMB's influence on the EPA was so substantial that

147. Regulatory Flexibility Act, Pub. L. No. 96-354, 94 Stat. 1164 (1980) (codified at 5 U.S.C. $\S ~ 601-612(1994))$.

148. Small Business Regulatory Enforcement Fairness Act of 1996, Pub. L. No. 104-121, $\S 203,110$ Stat. $857,857-58$.

149. Paperwork Reduction Act of 1980, Pub. L. No. 96-511, 94 Stat. 2812 (current version at 44 U.S.C. $\$ \$ 3501-3520$ (1994)).

150. Id. § 3503, 94 Stat. 2814-15.

151. See supra notes $131-50$ and accompanying text.

152. Office of Management and Budget Plays Critical Part in Environmental Policymaking, Faces Little External Review, 7 BNA ENV'T REP., May-Oct. 1976, at 696-97.

153. Implementation of the Clean Air Act Amendments of 1970_Part I: Hearings Before the Subcomm. on Air and Water Pollution of the S. Comm. on Public Works, 92d Cong. 325 (1972) (statement of William Ruckelshaus, EPA Administrator). 
both Ruckelshaus and his successor Russell Train asked President Nixon for written assurances that they would retain ultimate authority for EPA policy decisions as conditions for remaining in office. ${ }^{154}$ Russell Train explained in 1976 that he insisted on having the final say over regulatory decisions by the EPA to protect the agency's "regulatory integrity" in the eyes of the public, Congress, and other federal agencies. ${ }^{155}$ Yet it is clear that intense White House pressure affected some of his decisions, as when he ultimately agreed to delay for a year the effective date of regulations limiting the lead content of gasoline. ${ }^{156}$ Still the EPA retained a considerable degree of independence under Train, who openly disagreed with the White House when President Ford twice vetoed legislation regulating strip mining. ${ }^{157}$

President Carter's few attempts to influence regulatory decisions sparked controversy. Carter sought unsuccessfully to convince the secretary of labor to weaken OSHA's regulations to protect workers from exposure to cotton dust, regulations that later were upheld by the Supreme Court. ${ }^{158}$ Prior to the EPA's issuance of new source performance standards for coal-fired power plants, Carter called EPA Administrator Douglas Costle to the White House to discuss the regulations. ${ }^{159}$ This meeting provoked a legal challenge to the regulations by environmental groups that argued that the EPA's failure to document the meeting in the rulemaking record violated the Clean Air Act and denied them procedural due process. These arguments were rejected by the District of Columbia Circuit Court of Appeals in Sierra Club v. Costle.

3. Centralized Regulatory Review During the Reagan and George H. W. Bush Administrations. Although the Nixon, Ford, and

154. These events are described in a book by Train's deputy. JOHN QUARLES, CLEANING UP AMERICA: AN INSIDER'S VIEW OF THE ENVIRONMENTAL PROTECTION AGENCY 119 (1976) (reporting that President Nixon verbally agreed that the EPA administrator would retain ultimate authority for agency policy decisions, but that the agency subsequently "bargained in vain with OMB to spell out the change in writing").

155. Id.

156. Id. at $117-42$.

157. John Osborne, White House Watch: The Ford YeArs xvi (1977) (analyzing the policies of the Ford administration).

158. Am. Textile Mfrs. Inst., Inc. v. Donovan, 452 U.S. 490, 540 (1981) (stating that, through the Occupational Safety and Health Act in 1970, Congress "chose to place pre-eminent value on assuring employees a safe and healthful working environment, limited only by the feasibility of achieving such an environment").

159. Sierra Club v. Costle, 657 F.2d 298, 404 (D.C. Cir. 1981). 
Carter regulatory review programs were designed primarily to facilitate interagency dialogue, the Reagan administration's regulatory review program was designed primarily to reduce the burden of regulation by making it substantially more difficult for agencies to issue rules. On the first working day of his administration, President Reagan announced the formation of a Vice-Presidential Task Force on Regulatory Relief chaired by then-Vice President George H. W. Bush. ${ }^{160}$ The Task Force was charged with reducing regulatory burdens on industry. ${ }^{161}$ It suspended nearly 200 pending regulations and ultimately developed a "hit list" of 119 existing regulations (primarily environmental, health, and safety regulations) that it directed agencies to reconsider. ${ }^{162}$

On February 17, 1981, President Reagan launched his administration's program for review of new regulatory proposals by issuing Executive Order 12,291. ${ }^{163}$ This executive order mandated that agencies submit all proposed and final regulations to OMB's OIRA for review and that they refrain from publishing them in the Federal Register until OIRA's approval had been obtained. ${ }^{164}$ Rules likely to have an economic impact of $\$ 100$ million annually were to be accompanied by cost-benefit analyses called "regulatory impact analyses." 165 The Reagan regulatory review program quickly became the focus of considerable controversy. ${ }^{166}$

The Reagan program represented a significant departure from previous presidential efforts to influence rulemaking decisions by executive agencies in several respects. First, unlike previous programs that authorized selective review of particularly significant regula-

\footnotetext{
160. Percival, supra note 130, at 148 .

161. Id.

162. NAT'l ACAD. of Pub. Admin., Presidential Management of Rulemaking in REGULATORY AGENCIES 10 (1987).

163. Exec. Order No. 12,291 pmbl., 3 C.F.R. 127, 127 (1982) (seeking "to reduce the burdens of existing and future regulations ... and insure well-reasoned regulations").

164. Id. § 3(f), 3 C.F.R. at $128-30$.

165. Id. $\S \S 1(\mathrm{~b})(1),(3)(\mathrm{c}), 3$ C.F.R. at 127, 128-29.

166. See, e.g., Christopher C. DeMuth \& Douglas H. Ginsburg, White House Review of Agency Rulemaking, 99 HARV. L. REV. 1075, 1076 (1986) (explaining and responding to criticisms of President Reagan's regulatory review program); Alan B. Morrison, The Wrong Way to Write a Regulation, 99 HARV. L. REV. 1059, 1059 (1986) (arguing that "whatever theoretical legitimacy there may be for OMB involvement in the rulemaking process, its dominance under the present system is unwarranted"); Erik Olson, The Quiet Shift of Power: Office of Management \& Budget Supervision of Environmental Protection Agency Rulemaking Under Executive Order 12,291, 4 VA. J. NAT. RESOURCES L. 1, 1 (1984) (discussing OMB's authority to review EPA rules under Executive Order 12,291).
} 
tions, the Reagan program required that all proposed and all final regulations be submitted to OIRA for approval prior to publication. The Reagan program effectively enabled OIRA to block publication of regulations for an indefinite period of time.

Another significant feature of the Reagan program was that it established substantive criteria for agencies to use in setting regulatory standards. Agencies were instructed that they should not issue regulations unless their benefits exceed their costs, that they should choose regulatory alternatives that involve "the least net cost to society," and that regulatory priorities should be set to maximize "aggregate net benefits to society." ${ }^{\prime 67}$ This represented a substantial departure from the Carter administration's regulatory review program, which had encouraged agencies to develop cost-effective regulations while emphasizing that cost-benefit tests need not be satisfied. ${ }^{168}$

Finally, unlike the Regulatory Analysis Review Group review process, which took place on the public record during the comment period on proposed regulations, the Reagan program sought to shield regulatory reviews from public view. Although OIRA eventually adopted disclosure policies that allowed written exchanges between it and the agencies, to be released following the completion of review, OIRA's views typically were not incorporated into the public record, even in rulemakings under the Clean Air Act where Congress explicitly had required it. ${ }^{169}$

Concerned that regulatory review was taking place too late in the process to effect major changes in agency regulatory plans, the Reagan administration issued Executive Order 12,498 on January 4, $1985 .^{170}$ This executive order established a regulatory planning process that required agencies to submit annually to OIRA a draft regulatory program describing all significant regulatory actions they planned to undertake during the next year. ${ }^{171}$ Regulatory plans that were found to be consistent with the administration's policies and priorities were included in an annual publication called The Regulatory Program of the United States Government. ${ }^{172}$

167. Exec. Order 12,291 § 2(d)-(e), 3 C.F.R. at 128

168. George C. Eads, White House Oversight of Executive Branch Regulation, in SocIAL REGUlATION: STRATEGIES FOR REFORM 180-81 (Eugene Bardach and Robert A. Kagan eds., 1982).

169. Percival, supra note 130, at 152.

170. Exec. Order No. 12,498, 3 C.F.R. 323 (1986)

171. Id. § 2, 3 C.F.R. at 324.

172. E.g., Office of Mgmt. \& Budget, Regulatory Program of the United 
The Reagan administration's regulatory review program raised far more serious concerns about displacement of agency decisionmaking authority because it directed agencies not to issue proposed or final regulations until OMB approved them. To avoid legal problems, the executive order that established the Reagan program expressly stated that nothing in the order "shall be construed as displacing the agencies' responsibilities delegated by law." ${ }^{, 173}$ In its opinion supporting the legality of the Reagan program, the Department of Justice's Office of Legal Counsel emphasized that OMB's role in regulatory review was to be "advisory and consultative" only and that it did not include the authority to reject an agency's ultimate judgment on matters delegated to the agency by law. ${ }^{174}$

Although there is substantial evidence that OMB sought to abuse its regulatory review power during the Reagan administration to dictate decisions entrusted by law to agencies, ${ }^{175}$ the administration never expressly asserted the authority to do so. A court hearing a challenge to an OSHA regulation found it unnecessary to decide if OMB had acted unlawfully because the decision supposedly dictated by OMB was found not to have sufficient support in the rulemaking record. In Public Citizen Health Research Group v. Tyson, ${ }^{176}$ OSHA had been ordered by OMB to delete a short-term exposure limit from regulations controlling worker exposure to ethylene oxide. ${ }^{177}$ The court noted that "OMB's participation in the [ethylene oxide] rulemaking presents difficult constitutional questions concerning the executive's proper rule in administrative proceedings and the appropriate scope of delegated power from Congress to certain executive agencies." ${ }^{, 178}$ However, the court found it unnecessary to decide the

STATES GOVERNMENT, APR. 1, 1990-MARCH 31, 1991 (1990).

173. Exec. Order No. 12,291 § 3(f)(3), 3 C.F.R. 127, 130 (1982).

174. Memorandum from U.S. Dep't of Justice, Office of Legal Counsel (Feb. 13, 1981), reprinted in Role of $O M B$ in Regulation: Hearing before the Subcomm. on Oversight and Investigations of the House Comm. on Energy \& Commerce, 97th Cong. 486 (1981) (providing a proposed executive order entitled "Federal Regulation").

175. See Olson, supra note 166, at 6; EPA: Investigation of Superfund and Agency Abuses (Part 3): Hearings before the Subcomm. on Oversight and Investigations of the House Comm. on Energy \& Commerce, 98th Cong. 7-8 (1983) (testimony of John Daniel, former EPA Chief of Staff); id. at 234 (testimony of Anne McGill Burford, former EPA Administrator) (describing "some serious abuses" by OMB).

176. 796 F.2d 1479 (D.C. Cir. 1986).

177. Id. at 1483 .

178. Id. at 1507 . 
legality of OMB's actions because it found the decision to delete the short-term exposure limit was unsupported by the record. ${ }^{179}$

OMB was found by a court to have acted illegally when it blocked the EPA from issuing a regulation after a statutory deadline for promulgating it had expired. In Environmental Defense Fund $v$. Thomas, ${ }^{180}$ a federal district court declared that "OMB has no authority to use its regulatory review under EO 12291 to delay promulgation of EPA regulations . . . beyond the date of a statutory deadline." ${ }^{181}$ The court recognized that the use of regulatory review

to create delays and to impose substantive changes raises some constitutional concerns. Congress enacts environmental legislation after years of study and deliberation, and then delegates to the expert judgment of the EPA Administrator the authority to issue regulations carrying out the aims of the law. Under EO 12291, if used improperly, OMB could withhold approval until the acceptance of certain content in the promulgation of any new EPA regulation, thereby encroaching upon the independence and expertise of EPA. Further, unsuccessful executive lobbying on Capitol Hill can still be pursued administratively by delaying the enactment of regulations beyond the date of a statutory deadline. ${ }^{182}$

The administration of President George H. W. Bush continued the regulatory review program established during the Reagan administration. In 1989, it announced the creation of the Council on Competitiveness, chaired by Vice President Dan Quayle. ${ }^{183}$ The Competitiveness Council was charged with resolving disputes over regulatory review between OIRA and executive agencies. ${ }^{184}$ Its membership was tilted heavily toward the economic agencies. Its six permanent members included the director of OMB, the secretary of commerce, the secretary of the treasury, the chairman of the Council of Economic Advisers, the attorney general, and the White House chief of staff. ${ }^{185}$ In its most publicized action, the Council vetoed EPA Administrator William Reilly's attempt to include a twenty-five per-

179. Id.; cf. Nat'l Grain \& Feed Ass'n, Inc. v. OSHA, 866 F.2d 717, 729 n.22 (5th Cir. 1989) (stating that the "final rule must stand or fall on the basis of the record before the agency, not on the basis of some 'secret record' of OMB's").

180. 627 F. Supp. 566 (D.D.C. 1986).

181. Id. at 571.

182. Id. at 570 .

183. OFFICE OF MGMT. \& BUdGET, supra note 172, at 5.

184. Id.

185. Percival, supra note 130 , at 155. 
cent recycling requirement in a new source-performance standard for municipal incinerators. ${ }^{186}$

In December 1990, Reilly appealed to the Council to challenge OMB's rejection of a waste stream recycling requirement and a ban on incineration of lead acid batteries in a new source-performance standard for municipal incinerators. ${ }^{187}$ After the Council ruled in favor of OMB, Reilly withdrew the requirements from the regulations. ${ }^{188}$ When challenged in court, the deletion of the ban on incineration of lead acid batteries was remanded to the EPA for reconsideration because of the agency's failure to explain adequately its reasons for the deletion. ${ }^{189}$ However, the court upheld the decisions not to include the recycling requirement, finding that it had adequate support in the record. ${ }^{190}$ The court noted that the EPA's change of position "in light of the [Competitiveness] Council's advice... does not mean that EPA failed to exercise its own expertise in promulgating the final rules." ${ }^{191}$ This decision does not suggest that OMB or the Competitiveness Council had the authority to dictate the EPA's decision, particularly because it rests on the notion that the EPA continued to exercise its own expertise in accepting their advice. But the decision confirms that it would be very difficult, if not impossible, for the judiciary to police displacement if the agency accepts it.

President George H. W. Bush became directly involved in a few regulatory decisions, including a dispute over Food and Drug Administration (FDA) regulations to implement the Nutrition Labeling and Education Act of 1990. David Kessler, the commissioner of the FDA, has described how OMB (with the support of the Department of Agriculture) tried to require the FDA to modify its proposed food labeling regulations to mollify the meat industry, which wanted to obscure information about the fat content of foods. ${ }^{192}$ At a White House meeting, Health and Human Services Secretary Louis Sullivan

\footnotetext{
186. Id.

187. This appeal is described in New York v. Reilly, 969 F.2d 1147, 1148-50 (D.C. Cir. 1992).

188. Michael Weisskopf, EPA Proposal on Recycling Is Trashed; White House Panel Opposes Agency Plan, WASH. Post, Dec. 20, 1990, at A17 (stating that the Council "in its first major regulatory decision, urged Reilly to drop a proposal that the administration had touted just a year ago as a remedy to the nation's burgeoning solid waste problem").

189. Reilly, 969 F.2d at 1153.

190. Id.

191. Id. at 1152 .

192. KESSLER, supra note 1, at 56-57 (discussing his experience as the commissioner of the FDA).
} 
showed the president a McDonald's restaurant tray liner that contained nutritional information consistent with the FDA's approach. ${ }^{193}$ Sullivan argued that the FDA could not adopt the meat industry's proposal because it was not supported by the rulemaking record. ${ }^{194}$ This reportedly surprised President Bush, who stated:

"I'm a little puzzled. I'm being told that I can't just make a decision and have it promptly executed, that the Department can't just salute smartly and go execute whatever decision I make. Why is that?"195

Kessler reports that he and Sullivan were prepared to resign if the White House ordered the FDA to issue the rules sought by the meat industry. ${ }^{196}$ Instead, to their surprise, the president directed that the regulations preferred by the FDA be promulgated, though he did not accept the FDA's proposal to apply them to restaurants. ${ }^{197}$ This appears to be an example of the president's dictating a decision to an agency head. However, because he chose the decision generally favored by the agency, the agency head accepted the decision and did not resign in protest.

4. Presidential Management During the Clinton and George W. Bush Administrations. On September 30, 1993, President Clinton's regulatory review program was established by the issuance of Executive Order $12,866 .{ }^{198}$ The Clinton program returned to a far more selective approach to regulatory review. Only "significant regulatory actions" (defined to include those that have more than a \$100 million annual impact or other significant adverse effects) were subjected to review by OIRA. ${ }^{199}$ It also established a firm ninety-day deadline for completion of OIRA review, and it specified that the vice president should resolve disputes between agencies and OIRA. ${ }^{200}$

The Clinton administration's regulatory review program was far less controversial than those of the preceding administrations in part because it was much more selective and more transparent. However, President Clinton greatly expanded the issuance of formal presiden-

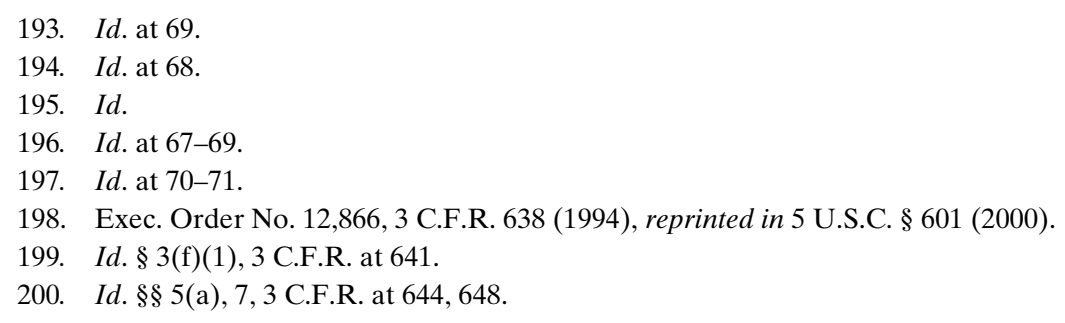


tial directives to executive agencies. Presidents Reagan and George H. W. Bush had issued only nine and four presidential directives, respectively, to executive agencies-three of these instructed agencies to delay or halt the issuance of regulations. ${ }^{201}$ By contrast, President Clinton issued 107 presidential directives, including many directing agencies to take regulatory action to deal with particular problems. ${ }^{202}$

Although President Clinton's regulatory review program was less controversial than those employed by the two previous administrations, in some respects it asserted greater presidential authority over agencies. Executive Order 12,866, which established the program, purported to subject independent agencies to OMB's regulatory planning process for the first time, though like its predecessors it did not require independent agencies to submit individual rules to OMB for review. ${ }^{203}$ Even more significantly, section 7 of the executive order provided that

$[t]$ o the extent permitted by law, disagreements or conflicts between or among agency heads or between OMB and any agency that cannot be resolved by the Administrator of OIRA shall be resolved by the President, or by the Vice President acting at the request of the President, with the relevant agency head (and, as appropriate, other interested governmental officials). ${ }^{204}$

After considering recommendations developed within sixty days by the vice president, this "conflict resolution" process is to culminate in notification to the agency and OMB "of the President's decision with respect to the matter."

This procedure for resolving disputes arising during the regulatory review process is similar to the way the George $\mathrm{H}$. W. Bush White House handled the dispute over the nutrition labeling regulations, though the Clinton executive order has strict requirements for disclosure of any outside lobbying: communications during the review period with any person not employed by the federal government have to be in writing and included in the public rulemaking docket. $^{206}$

\footnotetext{
201. Kagan, supra note 133, at 2294.

202. Id. at 2294-95.

203. Exec. Order No. $12,866 \S 4$ (c), 3 C.F.R. at $642-43$

204. Id. $\S 7,3$ C.F.R. at 648 .

205. Id.

206. Id. Kessler reports that during the nutrition labeling dispute, Craig Fuller, "who had been President Bush's chief of staff when Bush was vice president" was lobbying the White
} 
Kessler reports that President Bush resolved the nutrition labeling dispute by deciding not only what calorie count the regulations should recommend, but also what the specific design format for a nationwide, standardized nutrition label for all non-meat and processed meat products should be. ${ }^{207}$

Because the Clinton administration's regulatory review program generally was so well received, the controversy over presidential oversight of rulemaking died down. ${ }^{208}$ In large part this was because President Clinton pursued a far more balanced approach to regulatory policy. Rather than focusing exclusively on reducing regulatory burdens to industry, the Clinton administration used presidential directives to spur agencies to take actions to improve public health, safety, and environmental protections. Describing this pattern as "presidential administration," Professor Elena Kagan argues that it demonstrates that enhanced presidential control over administration can serve pro-regulatory objectives. ${ }^{209}$ Kagan, who served in the Clinton White House, argues that President Clinton acted to assert personal ownership over executive agencies' regulatory activity by issuing directives to agencies to influence their regulatory priorities and by visibly taking credit for regulatory initiatives that supported his political agenda. ${ }^{210}$ As a result of this activity, Kagan maintains that the president has, at least for now, achieved primacy in directing and influencing the outcome of the regulatory process. ${ }^{211}$

Kagan notes, however, that President Clinton's assertion of "directive authority" over the actions of executive agencies raises even more serious constitutional questions than the Reagan administration's regulatory review program. ${ }^{212}$ These include the question addressed in Part IV of this Essay: whether the president has the authority to dictate decisions entrusted by law to agency heads.

\footnotetext{
House as a lobbyist for Kraft, which opposed labeling requirements that would not allow their cheeses to be identified as "light" in fat content. KESSLER, supra note 1, at 58.

207. Id. at 70-71.

208. See JefFrey S. Lubbers, A Guide to Federal Agency Rulemaking 28-29 (3d ed. 1998) (stating that the issues surrounding presidential review have "gradually evolved into a fairly broad agreement that it is not only legal, but that if properly administered, it is essential to effective executive branch management").

209. Kagan, supra note 133, at 2282.

210. Id.

211. Id. at 2319

212. Id.
} 
The Clinton administration's assertion of presidential authority to resolve disputes between agencies is somewhat less troubling from a constitutional perspective than the notion of its resolving disputes between OMB and an agency. In circumstances where there is a dispute between two cabinet agencies that are pursuing incompatible approaches to a regulatory issue (as in the nutrition labeling example in which the Department of Health and Human Services and the Agriculture Department were fundamentally at odds), the case for having the president or vice president resolve the dispute is considerably stronger because the White House is uniquely situated to resolve conflicts between agencies. But if the dispute is between OMB and an agency head, a directive from the White House instructing the agency head how the dispute is to be resolved looks suspiciously like displacement of decisionmaking authority entrusted to agency heads by law.

In her excellent defense of the Clinton administration's brand of presidential administration, Professor Kagan distinguishes the Steel Seizure case on the ground that Congress had not passed any law authorizing the president or the secretary of commerce to seize the steel mills. She maintains that because considerable regulatory legislation authorized the very actions President Clinton directed agency heads to undertake, the Steel Seizure Case does not undermine the legality of Clinton's actions. ${ }^{213}$ Professor Kagan suggests that if Congress had authorized the secretary of commerce to seize the steel mills, President's Truman's action would have been legal even though Congress had entrusted the decision to the secretary of commerce and not to the president. ${ }^{214}$

Kagan's view is not founded on the unitary executive theory, which, as demonstrated above, is inconsistent not only with the historical understanding of Article II as reflected in the first Congress's establishment of federal agencies, but also with the Court's decision upholding the constitutionality of legislative restrictions on the president's removal power. ${ }^{215}$ But Kagan argues that where Congress has not acted expressly to restrict the president's ability to direct an administrative agency to act, courts should interpret federal statutes to permit the president to do so. ${ }^{216}$ Kagan maintains that such an inter-

213. Id. at 2321 .

214. Id. at 2321-22.

215. See supra notes 48-67, 79-103 and accompanying text.

216. Kagan, supra note 133, at 2327-28. 
pretive principle ("presuming an undifferentiated presidential control of executive agency officials") may be a more accurate interpretation of Congress's true intent. ${ }^{217}$

Kagan's argument may find a receptive audience among some members of the Supreme Court who currently appear to favor clear statement requirements when interpreting statutes that impinge on interests they seek to protect. ${ }^{218}$ But given the assumption that prevailed when the current regulatory statutes were enacted-that the president did not have the authority to dictate regulatory decisions entrusted to agencies by law-it is hard to make a case that Congress needed to enact legislation that specifically prohibited displacement for the president to be foreclosed from displacing agencies' decisions. As noted above, every regulatory review program since the rise of the administrative state has been founded on the notion that the president did not have the authority to displace agency decisionmaking. ${ }^{219}$ Thus, it is hardly surprising that while some legislation delegates decisions to the president, other legislation delegates decisions to agency heads without including specific directives prohibiting the president from dictating the decisions. The fact that the president may in turn redelegate decisions entrusted to him by law also does not imply that he has the authority to dictate decisions instead entrusted by law to other executive officials.

Presidential review of rulemaking by executive agencies is likely to become more contentious under the George W. Bush administration, which is far more skeptical of regulation than the Clinton administration was. On the day that the Bush administration took office, White House Chief of Staff Andrew Card, Jr., issued a memorandum to the heads of all executive department agencies directing them not to send any proposed or final regulations to the Federal Register without the approval of a Bush appointee and to withdraw all regulations that had been sent to the Federal Register which had not yet been published, except for rules dealing with emergency situations. ${ }^{220}$

217. Id. at 2328

218. See, e.g., Solid Waste Agency v. U.S. Army Corps of Eng'rs, 531 U.S. 159, 170-73 (2001) (interpreting narrowly the reach of the Clean Water Act in the absence of clearer evidence that Congress intended to impinge on federalism values).

219. See supra notes 151-59, 173-74 and accompanying text.

220. Memorandum from Andrew H. Card, Jr., White House Chief of Staff, to the Heads and Acting Heads of Executive Departments and Agencies (Jan. 20, 2001), available at http:// www.whitehouse.gov/news/releases/20010123-4.html. 
Although the Bush administration ultimately decided not to reconsider several regulations promulgated toward the end of the Clinton administration, its initial decision to reconsider tighter limits on arsenic in drinking water sparked considerable criticism. ${ }^{221}$ This criticism was so intense that the EPA announced in October 2001 that it had decided to implement the Clinton administration rule lowering the maximum contaminant level for arsenic in drinking water from fifty to ten parts per billion. ${ }^{222}$

The most prominent regulation rescinded by the Bush administration was a regulation promulgated by OSHA. With the support of the Bush administration, Congress used the provisions of the Congressional Review Act (CRA) ${ }^{223}$ for the first time in March 2001 to veto OSHA's ergonomics standard, which had been under development by the agency for nearly a decade. ${ }^{224}$ The CRA requires agencies to send all regulations to Congress for review sixty days before

221. The decision to reconsider the arsenic rule provoked considerable public outrage. Public opinion polls showed that it was intensely unpopular. Cass R. Sunstein, The Arithmetic of Arsenic (Aug. 2001) at http://www.Aei-brookings.org/publications/working/working_01_10. pdf (on file with the Duke Law Journal). Editorial writers harshly denounced it. See Robert K. Musil, Arsenic on Tap, N.Y. TIMES, Apr. 24, 2001, at A18. The Democratic party quickly filmed a television commercial attacking the decision by having a small child ask her mother for more arsenic. See Michael Kelly, Bush's Summer Vacation Is Almost Over, TownHall.com Columnists, Aug. 22, 2001, at http://www.townhall.com/columnists/michaelkelly/mk20010822. html (on file with the Duke Law Journal). The former EPA official responsible for the rule during the Clinton administration denounced the decision as an "action [that] will jeopardize the health of millions of Americans" and that "compromises literally a decade's worth of work on behalf of developing a public health standard." Douglas Jehl, EPA to Abandon New Arsenic Limits for Water Supply, N.Y. TIMES, Mar. 21, 2001, at A1; see also Jeanne Cummings \& John Harwood, Arsenic Issue May Poison Bush's “Compassionate Conservatism,” WAll ST. J., Apr. 20, 2001, at A16 (discussing environmentalists' response to the new administration's reconsideration of the arsenic regulations and examining President George W. Bush's conservative political background); Peter Waldman, Dangerous Waters: All Agree Arsenic Kills; The Question Is How Much It Takes to Do So, WALl ST. J., Apr. 19, 2001, at A1 (describing scientific evidence supporting the regulation of arsenic levels in drinking water).

222. Office of Water, United States Environmental Protection Agency, EPA to Implement 10 ppb Standard for Arsenic in Drinking Water, at http://www.epa.gov/safewater/ars/ars-octfactsheet.html (Oct. 2001) (on file with the Duke Law Journal).

223. 5 U.S.C. $\$ \S 801-808(2000)$.

224. On March 1, 2001, congressional Republicans introduced a resolution of disapproval that was approved by the Senate on March 6, 2001, by a vote of 56-44. On March 7, the House of Representatives adopted the joint resolution by a vote of 223-206. OSHA had expected that its ergonomics rules would prevent 500,000 worker injuries per year from carpal tunnel syndrome, back strains, and other ailments. 65 Fed. Reg. 68,262 (Nov. 14, 2000). OSHA acknowledged that the rule would be expensive for businesses, estimating that it ultimately could cost $\$ 4.5$ billion to implement, but it projected that it would save $\$ 9$ billion per year by reducing worker injuries. $I d$. 
they take effect and it creates a special fast-track procedure to enable Congress to enact joint resolutions disapproving regulations. ${ }^{225}$ If Congress enacts a joint resolution of disapproval, the regulation shall not take effect or continue in effect, and the agency that issued the measure is prohibited from issuing any new rule that is "substantially the same as" the disapproved rule unless specifically authorized by subsequent legislation. ${ }^{226}$

Using the fast-track procedures of the CRA, the joint resolution disapproving OSHA's regulation was adopted without any hearings or committee action, with no opportunity for amendments, and with floor debate limited to ten hours in the Senate and one hour in the House. ${ }^{227}$ President Bush endorsed the disapproval effort ${ }^{228}$ and signed the joint resolution repealing the rule. Many of those who voted to repeal the rule stated that they were not opposed to having an ergonomics standard, but that they objected to the particular standard that OSHA adopted. ${ }^{229}$ Labor Secretary Elaine Chao announced that the department would consider a new rule to protect workers from repetitive-motion injuries. ${ }^{230}$ Others, however, believe that the CRA precludes OSHA from issuing a new ergonomics rule without new legislation specifically authorizing it to do so. ${ }^{231}$

President Bush's support for using the CRA to veto OSHA's ergonomics standard actually may reinforce the notion that the president does not have the power to dictate regulatory decisions by agencies. Otherwise he simply could have directed OSHA to repeal the standard. If the president has the authority to dictate agency decisions, then it is hard to envision why President Clinton would have signed the CRA into law. If the president can exert complete control over agency rulemaking decisions, he would not need a vehicle to re-

225. 5 U.S.C. $\$ \S 801-802$.

226. Id. § 801(b)(2). In INS v. Chadha, 462 U.S. 919 (1983), the Supreme Court held that a legislative veto of regulations is unconstitutional because it bypassed the president's role in approving or disapproving of legislation. Id. at 951-59. The Congressional Review Act avoids this constitutional problem by providing that joint resolutions of disapproval either must be signed by the president or enacted over his veto. 5 U.S.C. $\$ 801(\mathrm{a})(3)$.

227. Steven Greenhouse, House Joins Senate in Repealing Rules on Workplace Injuries, N.Y. TIMES, Mar. 8, 2001, at A19.

228. Kathy Chen, Effort to Kill Workplace Ergonomics Rules Gains Steam as Bush Gives Endorsement, WALL ST. J., Mar. 7, 2001, at A3.

229. Greenhouse, supra note 227, at A19.

230. David Rogers \& Kathy Chen, House Joins Senate in Killing Ergonomics Rules, WaLL ST. J., Mar. 8, 2001, at A2.

231. Greenhouse, supra note 227 , at A19. 
peal them. However, the circumstances surrounding the repeal of OSHA's ergonomics regulation-occurring in the early days of a new administration to repeal a rule issued by the outgoing administration of a president from a different political party ${ }^{232}$ - probably reflects the already high degree of presidential control over rulemaking. Because the president can veto resolutions disapproving rules under the CRA, it is unlikely to be used frequently (OSHA's ergonomics regulation is the only one that has been repealed using the CRA) except in circumstances where a new president seeks to block rules issued by a prior administration.

The Bush administration continues to conduct regulatory review under Executive Order 12,866 while developing its own review program that is widely expected to subject regulations to more intense scrutiny. President Bush's nomination of Harvard professor John Graham to be OIRA administrator was opposed vigorously by environmental and consumer groups that argued that he was too sympathetic to corporate interests. ${ }^{233}$ On July 19, 2001, the Senate confirmed Graham's appointment by a vote of $61-37 .{ }^{234}$ In an effort to demonstrate that he plans to be even-handed in conducting regulatory review, Graham has announced that OIRA will issue "prompt" letters to agencies to direct their attention to issues that deserve greater regulatory attention. ${ }^{235}$ In September 2001, OIRA sent prompt letters to OSHA and to the Department of Health and Human Services. ${ }^{236}$ The letter to OSHA encouraged the agency to require companies to use automated external defibrillators to prevent deaths from heart attacks. ${ }^{237}$ The letter to the Department of Health and Human Serv-

232. See Chen, supra note 228, at A3.

233. See, e.g., Dick Durbin, Graham Flunks the Cost-Benefit Test, WASH. Post, July 16, 2001, at A15 (explaining Graham's opposition to private sector regulation based on risk analysis).

234. U.S. Senate Roll Call Votes, 107th Congress-1st Session (July 19, 2001), at http://www. senate.gov/legislative/vote1071/vote_00242.html (on file with the Duke Law Journal).

235. See Memorandum from John D. Graham, Administrator, Office of Information and Regulatory Affairs, Office of Management and Budget, to the President's Management Council, regarding Presidential Review of Agency Rulemaking by OIRA, at 5 (Sept. 20, 2001), available at $\mathrm{http}: / / \mathrm{www}$.whitehouse.gov/omb/inforeg/oira_review-process.html (on file with the Duke Law Journal) (describing the meaning of "prompt" letters).

236. Ellen Nakashima, OMB Asks Agencies for Action, WASH. Post, Sept. 21, 2001, at A30.

237. Id. 
ices encouraged it to require food labeling that would disclose transfatty acid content. ${ }^{238}$

\section{POLICY CONSIDERATIONS}

Is it legal for the president to dictate the substance of regulatory decisions that a statute requires an agency head to make? It appears highly significant that no president has expressly asserted such authority. Indeed, even though the Clinton administration's program provides that disputes between OMB and agencies are to be resolved by the president, the executive order that creates the program states that "[n]othing in this order shall be construed as displacing the agencies' authority or responsibilities, as authorized by law." ${ }^{239}$ Thus, even the Clinton program is founded on the premise that agencies retain responsibility for decisions entrusted to them by law.

The sparse case law in this area makes it clear that the president does not have the authority to dictate a decision that is not in accordance with the facts in the rulemaking record or the standards required to be employed by the underlying regulatory statute. However, it also suggests that if the agency head is persuaded by the president to adopt as the agency's own the outcome preferred by the White House, the decision will not be subject to judicial reversal if it is consistent with the facts in the rulemaking record and the standards required by the underlying regulatory statute. If the agency head is not persuaded by the president, he or she can be fired, subject to whatever limitations on removal Congress has enacted, but the president cannot himself issue the regulations adopting his preferred outcome.

As a practical matter, the president's ability to fire agency heads makes it likely that he will win most policy disputes with them. However, adherence to the view that the president does not have the authority to dictate decisions entrusted to agency heads by law creates a distinction that can make a very real difference to policy outcomes for several reasons. First, there is a substantial political cost to the president if he has to fire an agency head who disagrees with the policy outcome the president prefers. ${ }^{240}$ Because the president has not been thought to have the power to dictate decisions entrusted to

238. Id.

239. Exec. Order No. 12,866 § 9, 3 C.F.R. 638, 649 (1994), reprinted as amended in 5 U.S.C. $\S 601(2000)$.

240. Pildes \& Sunstein, supra note 6 , at 25 . 
agencies by law, agency heads have somewhat more power to resist White House efforts to force them to grant favors to special interests. ${ }^{241}$ Precisely because the president's removal authority is such a powerful weapon in his arsenal of tools to persuade agencies to adhere to his policies, when an executive official refuses to do so, it usually indicates that some broader principle is at stake. This can serve as an alarm signal to the public that the president may not be acting with fidelity to the law or in the best interest of the country.

The Watergate "Saturday Night Massacre" spawned by President Nixon's efforts to remove Watergate special prosecutor Archibald Cox illustrates the political costs to the president of having to fire executive officials to work his will. ${ }^{242}$ When Cox was appointed, the Justice Department issued an order granting him the "greatest degree of independence that is consistent with the Attorney General's statutory accountability" and pledging that the "Attorney General will not countermand or interfere with the Special Prosecutor's decisions or actions." 243 The order also provided that the special prosecutor would not be removed "except for extraordinary improprieties on his part." ${ }^{244}$ Both Attorney General Elliot Richardson and his deputy William Ruckelshaus resigned rather than carry out the president's order to fire Cox, which they viewed as illegal and improper. Robert Bork, who then became acting attorney general, agreed to carry out the order, though he was unable to make a claim that Cox's removal was for "extraordinary improprieties." 245 The political firestorm that these firings engendered resulted in Cox's successor, Leon Jaworski, being granted by Congress even more substantial protection from removal.

241. Early in the EPA's history, a Nixon White House aide asked the EPA to seek a stay of a court order the EPA had won in one of its first enforcement actions against a company the president of which was a politically important Republican. The White House backed off after EPA Administrator William Ruckleshuas threatened to resign "if environmental decisions are overruled because of political considerations." QUARLES, supra note 154, at 58-76. EPA Administrator Russell Train threatened to resign when the White House sought to force him to support legislation to weaken the Clean Air Act during the first Arab oil embargo in 1973. Id. at 141 . The White House staff ultimately was forced to back down. Id.

242. For a more complete account of the "Saturday Night Massacre," see generally KEN GORMLEY, ARCHIBALD COX: CONSCIENCE OF A NATION 361-72 (1997).

243. Establishing the Office of Watergate Special Prosecution Force, 38 Fed. Reg. 14,688 (June 4, 1973).

244. Id.

245. A suit brought by Ralph Nader and several members of Congress resulted in a judgment that Cox had been discharged illegally. Nader v. Bork, 366 F. Supp. 104, 108 (D.D.C. 1973). 
An argument can be made that it makes no difference which party has the entitlement to decisionmaking authority-the president or the agency head-because agency officials can either be fired by the president to achieve his ends or they can resign in protest if a decision they oppose is dictated to them, producing the same policy result with approximately the same political cost to the president. However, this is probably a case where the initial assignment of entitlement to make a decision has an impact on bargaining power. If the president has no right to dictate a decision entrusted by law to an agency head, the agency head will be bargaining with greater moral authority than she would have if she knew the president had a right to dictate the decision. Moreover, because the costs of firing and the costs of resignation probably differ for each party, there are circumstances in which officials would not be fired for making decisions over which they would not be willing to resign. Thus, a president who has directive authority should find it easier to persuade agency officials to accept policies that they would not adopt on their own.

It also can be argued that giving directive authority to a president would undermine the value of the Senate's constitutional function in providing advice and consent to the president's appointments of agency heads. Although presidents tend to appoint officials who are likely to agree with their policies, the need to obtain their confirmation by the Senate can have a substantial impact on the types of people who ultimately take the helm of executive agencies. If the president has the legal authority to dictate decisions entrusted to agencies by law, then it makes little difference whom the president appoints. Indeed, the White House could assume (at least in theory) all the functions of an executive agency knowing that the president's directive authority makes it irrelevant who the actual decisionmaker is.

Even those who readily agree that the president is entitled to appoint cabinet heads who share his philosophy believe that confirmation hearings serve a useful function by permitting an exploration of the "likely regulatory approaches" and "policy background" of the nominee..$^{246}$ The confirmation process often is used by members of the Senate to obtain assurances from prospective agency heads that they will implement the authorities entrusted to them with some degree of independence from the president's political preferences. If the president has, and regularly uses, the authority to dictate agency decisions,

246. Dellinger, supra note 3, at A22. 
then it makes less difference who occupies the seat at the cabinet table. Thus, in the steel seizure example, if Congress had enacted a statute authorizing the secretary of commerce to seize the steel mills if he made certain findings, the mills could be seized only if the secretary of commerce agreed to make the necessary finding. If the secretary refused, he could be fired by the president who would pay a higher political cost for having to install a replacement official willing to make the finding.

Once agency officials take office, their institutional responsibilities influence their policy agendas. Although this may make it more difficult for the president to control what agencies do, it is an entirely legitimate product of congressional delegations to agencies. When he was director of OMB during the first Reagan administration, David Stockman was shocked that many cabinet heads opposed issuance of Executive Order 12,291 because it threatened their decisionmaking prerogatives. Stockman had assumed that this was a "safe item" because "[s]weeping deregulation was another pillar of Reagan's supply-side platform" and regulatory review "had become an article of faith among conservative critics of the regulatory superstate." ${ }^{247}$ Stockman concluded that his cabinet colleagues "were ill-schooled in even the basic tenets of the Reagan Revolution" and were becoming captives to what he described as the "permanent bureaucracies" within their agencies. ${ }^{248}$ In retrospect, Stockman should not have been surprised that agency heads were simply seeking to defend what they viewed as their institutional roles. If the president had authority to dictate agency decisions, he effectively could circumvent the administrative structure erected by Congress by transferring ultimate decisionmaking authority away from agency heads.

The argument in favor of presidential authority to dictate agency decisions confronts not only legal difficulties, but also substantial policy concerns. Although it may have become somewhat oldfashioned to speak of agency expertise, any effort to involve the White House in more than a handful of regulatory decisions necessarily must delegate presidential authority to persons who often are likely to have far less expertise than the agency officials whose decisions they seek to displace. The president simply does not have the time to be personally involved in any more than a few of the myriad,

247. David A. Stockman, The Triumph of Politics: How the Reagan Revolution FAILED 103 (1986)

248. Id. 
complex regulatory issues with which agencies grapple on a daily basis. Thus, one consequence of efforts by the Clinton administration and now the George W. Bush administration to assert greater White House authority over agency policies is that young White House aides are now trying to give orders to cabinet officials. ${ }^{249}$

In his book Locked in the Cabinet, President Clinton's first secretary of labor, Robert Reich, describes how he repeatedly felt bullied by phone calls from young aides in the White House Office of Cabinet Affairs. After being informed that "[t]he White House wants you to go to Cleveland," Reich describes his reaction:

Here I am, a member of the president's cabinet, confirmed by the Senate, the head of an entire government department with eighteen thousand employees, responsible for implementing a huge number of laws and rules, charged with helping people get better jobs, and who is telling me what to do? Some twerp in the White House who has no clue what I'm doing in this job. Screw him. I won't go. ${ }^{250}$

Similar complaints are now being voiced by members of the Bush cabinet. ${ }^{251}$ Although its members include former governors and senators and top business executives, the Bush cabinet is now viewed as far less influential than the White House staff in developing policy initiatives. This perception is reflected in the remark by current cabinet member Norman Mineta that "I'm the secretary of the Department of Transportation, but I'm still only staff to the president of the United States." ${ }^{252}$

Before Congress made extensive delegations of rulemaking power and other legal responsibilities directly to agency heads, its delegations to the president were so extensive as to require the president to turn over many functions to subordinate officers. As one study observed in 1924: "There is no way in which this could be prevented. Were it not for the possibility of devolution in all ordinary cases we should have to evolve supermen for our Presidents." 253 The president's need to delegate responsibilities to subordinates was so

249. This has been a frequent criticism of regulatory review by OMB. See, e.g., Percival, supra note 130, at 181-82 (describing criticism of OIRA reviews performed by desk officers who have neither the technical expertise nor the administrative guidance to appropriately review new regulations).

250. ROBERT B. REICH, LOCKED IN THE CABINET 109 (1997)

251. Ellen Nakashima \& Dana Milbank, Bush Cabinet Takes Back Seat in Driving Policy, WASH. Post, Sept. 5, 2001, at A1.

252. Id.

253. HART, supra note 14 , at 187. 
acute that an issue frequently addressed by the Supreme Court was whether agency action could be considered the action of the president for purposes of performing functions entrusted to the president by Congress. ${ }^{254}$ Some matters were deemed so important that they required some showing that they had received the personal attention of the president before they would be deemed valid. ${ }^{25}$

Elena Kagan argues that a congressional intent to bar the president from deciding issues delegated by law to agency heads should not be inferred from the fact that Congress delegates other functions to the president. She argues that congressional delegations of authority to the president have a different effect than delegations to agency heads because the former enable the president to choose who the initial decisionmaker will be. ${ }^{256}$ Kagan argues that the fact that Congress has chosen to delegate some responsibilities directly to agency heads means only that Congress has placed initial responsibility on the agency head, but not necessarily that it intended to foreclose the president from taking ultimate responsibility for the decision. $^{257}$ Yet there are some circumstances in which Congress has specified that the legal effects of certain decisions entrusted to agency heads may be suspended by the president upon a finding of some sort of national emergency. ${ }^{258}$ If the president has express authority to overturn the legal consequences of agency decisions in some circumstances, but not others, the argument for inferring congressional intent to permit the president generally to displace agency decisions is somewhat weaker.

254. See, e.g., Wilcox v. Jackson, 38 U.S. (13 Pet.) 498, 513 (1839) (explaining that an order by the War Department reserving public lands from sale is "in legal contemplation the act of the President" because "[t]he President speaks and acts through the heads of the several departments in relation to subjects which appertain to their respective duties"); see also Boske v. Comingore, 177 U.S. 459, 467-70 (1900) (affirming a district court order releasing from the custody of state law enforcement officers an Internal Revenue Service (IRS) agent who refused to hand over to state officials private business records pursuant to federal regulations limiting the use of such records by the IRS).

255. See, e.g., Runkle v. United States, 122 U.S. 543, 557-61 (1887) (requiring that for a sentence of a court martial to be valid, it has to be shown to represent the personal decision of the president).

256. Kagan, supra note 133, at 2329.

257. Id.

258. See, e.g., Clean Air Act, Pub. L. No. 95-95, § 107(f), 91 Stat. 691-93 (1977) (codified as amended at 42 U.S.C. $\$ 7410$ (f) (1994)) (allowing the president, and only the president, to determine that a national or regional energy emergency of such severity exists that portions of applicable state air quality controls can be suspended). 
A major argument used by proponents of presidential authority to dictate agency decisions is that such authority will foster greater accountability by making it clear that the president bears the ultimate responsibility for regulatory decisions and by making the bureaucracy more accountable to a nationally elected official. However, it also can be argued that by allowing the president to countermand agency decisions, accountability would be blurred because in many cases the public would be unable to understand whether a decision was the product of the agency's expertise or a presidential directive. One criticism of the OMB review process during the Reagan and George $\mathrm{H}$. W. Bush administrations is that the process often forced agencies to alter their policies to satisfy OMB's preferences without the responsible persons' leaving any fingerprints. Former EPA Deputy Administrator John Quarles argues that

it is preferable to rely on the political process to hold the Administrator accountable rather than to create complex mechanisms which attempt to establish additional checks and balances within the executive branch, but which also inevitably fragment responsibility and in the end undermine achievement of the very accountability for which those mechanisms are established. ${ }^{259}$

The Supreme Court has stated that when one level of government "commandeers" the regulatory process of another by compelling it to adopt unpopular regulations, the political accountability of both is diminished, because the officials whose decisionmaking processes are commandeered "will bear the brunt of public disapproval," while the officials who compelled the unpopular action "may remain insulated from the electoral ramifications of their decision.," ${ }^{, 60}$ Thus, the Court concluded that federal officials had to at least give states a choice whether to regulate on their own, even if the threat of losing federal funds or having the federal government regulate in lieu of the state were very likely to persuade the state to act. Although the impact of presidential involvement in agency decisions on accountability may turn in large part on what sort of public disclosure is required, the Court's logic suggests that allowing the president to dictate decisions by agency heads may raise accountability concerns. Some agency heads have been very successful in using publicity to

259. Executive Branch Review of Environmental Regulations: Hearings Before the Subcomm. on Envtl. Pollution of the S. Comm. on Env't and Public Works, 96th Cong. 4 (1979) (statement of John Quarles, Deputy Director, EPA).

260. New York v. United States, 505 U.S. 144, 169 (1992). 
rally public support for their preferred decisionmaking outcomes. If the president can secretly dictate the decisions they must make, accountability could suffer.

If the president had the authority to dictate regulatory decisions to agency heads, there is reason to suspect that the White House would be more inclined to intervene to achieve short-term political gains than to promote the objectives of regulatory statutes Congress has entrusted agencies to administer. Had the White House been able to dictate regulatory decisions, the world would be very different today. The EPA's initial effort to limit levels of lead additives in gasoline might never have gotten off the ground, ${ }^{261}$ and, even if it had, the limits probably would have been abandoned in 1982 when the VicePresidential Task Force on Regulatory Relief advised the EPA to eliminate them. ${ }^{262}$ Warning labels would not have been mandated for cigarettes in 1965 if the Federal Trade Commission had acceded to a White House request to abandon the rulemaking that spurred enactment of the Federal Cigarette Labeling and Advertising Act. $^{263}$ Workers in the textile industry would not have the full benefits of OSHA's cotton dust standard. ${ }^{264}$ These are only some of the many regulations that have produced enormous net benefits to society, but that the White House sought to block or weaken.

The Clinton administration's experience demonstrates that presidential review of rulemaking need not be biased against regulation. President Clinton used the energy of his office to focus agencies' attention on problems that he felt were not being adequately addressed. Early indications suggest that the George W. Bush administration may take a similar approach toward regulatory review by issuing "prompt" letters to suggest problems deserving of agency attention.

Attitudes toward presidential involvement in rulemaking are inescapably shaped by one's views concerning the desirability of regulation, the quality of decisionmaking by regulatory agencies, and the objectives served by regulatory review. Critics of regulation and

261. QUARLES, supra note 154 , at $117-42$.

262. Percival, supra note 130, at 187-88.

263. See RichARd KLUGER, AsHes to AsHes 269 (1996) (reporting that White House officials asked Rand Dixon, chairman of the FTC, to halt the FTC rulemaking process that would have resulted in a warning label requirement). At the time, President Johnson's close friend, Abe Fortas, who later became a Supreme Court Justice, was working as one of the principal Washington lobbyists for the Philip Morris Company. Id. at 270.

264. See supra note 158 and accompanying text. 
regulatory agencies typically portray them as vehicles for special interest "rent seeking,",265 while environmental and consumer groups portray them as champions of the public interest. Prior to the Clinton administration, virtually all presidential involvement in rulemaking was designed primarily to make it more difficult for agencies to regulate to reduce costs to industry, rather than to achieve its purported goal of increasing the net benefits of regulation to society. ${ }^{266}$ The Clinton administration pursued a more balanced approach in which the president also sought to spur agencies to take action. ${ }^{267}$

\section{CONCLUSION}

Each of the regulatory review programs established by every president since Richard Nixon has been founded on the notion that the president should play an advisory and consultative role in supervising rulemaking by executive agencies. By this view, the president may advise agency heads concerning his views on particular rules, but the president has no authority to dictate regulatory decisions entrusted to them by law. This Essay argues that this understanding is well grounded in the Constitution, the history of Congress's creation of executive agencies, and the sparse judicial precedents concerning the limits of presidential power. Because the president has the authority to fire agency heads, he can have substantial influence over their decisions. He may persuade agency heads to change their minds about regulatory decisions so long as the rules they adopt are supported by evidence in the rulemaking record and are consistent with standards required by the underlying regulatory statute. But the agency head retains the ultimate authority for regulatory decisions entrusted to her by law, and the president may not dictate what her decision will be.

This results in a less unitary executive than envisioned by those who argue that independent agencies violate constitutional principles

265. See, e.g., C. Boyden Gray, Special Interests, Regulation, and the Separation of Powers, in The Fettered Presidency: Legal Constraints on the Executive Branch, supra note 10, at 211, 214-21 (describing several examples of concentrated benefits to special interests in the regulation of, among other things, sulfur emissions from coal-fired power plants, airbags in cars, and the drug approval process).

266. Percival, supra note 130, at 184-89.

267. See generally Kagan, supra note 133 (arguing that the Clinton administration's approach to regulatory review "provoked fewer confrontations" than previous administrations' approaches but "articulated a broader understanding of the President's appropriate authority to direct administrative actions"). 
of separation of powers and that the president should have the authority to dictate decisions by all executive officers (views undermined by recent Supreme Court decisions). It also represents sound policy that accommodates the interests of Congress and the president in their continuing competition for influence over regulatory policy, while providing a check on presidential abuse of power.

As the sparse judicial precedents indicate, the judiciary will tread lightly when addressing issues of presidential power. The Constitution is purposefully vague in many regards, a fact that facilitates continuing competition between the three branches of government for influence over regulatory policy. Whether envisioned by the Framers or not, this competition is a healthy development that illustrates the vitality and adaptability of the nation's structure of government and the system of checks and balances that prevents any single branch from overreaching.

A president who could dictate regulatory outcomes would not need all the vigor and energy that the Framers sought to give the office when investing it with the executive power. Nor would the president be as inclined to listen to dissent from cabinet officers who may have valuable ideas. ${ }^{268}$ One important reason presidents like Theodore Roosevelt and Bill Clinton were successful in mobilizing the executive branch to pursue their regulatory agendas is because of their extraordinary powers of persuasion. Political scientist Richard Neustadt captured it best when he wrote that presidential power "is the power to persuade." ${ }^{269}$ Although external events can have a dramatic impact on the extent of presidential power, a president who wishes to play an active role in management of the administrative state must be prepared to use the formidable powers of persuasion the presidency provides.

Near the close of his first year in office, President George W. Bush has just made two highly controversial decisions that raise fundamental questions concerning presidential authority and the use of executive orders. On November 1, 2001, the president issued Executive Order 13,233, which asserts that the sitting president has the authority to control the release of presidential papers from both cur-

268. See, e.g., Stephen Power, Transportation Secretary Opposes Private Air-Traffic Control System, WALL ST. J., Mar. 14, 2001, at B2 (reporting Transportation Secretary Norman Mineta's opposition to the privatization of the air-traffic control system, "a stance potentially at odds" with the George W. Bush administration).

269. Richard E. Neustadt, Presidential Power and the Modern Presidents 11 (1990) 
rent and past administrations. ${ }^{270}$ This action, which effectively blocked the imminent public release of documents from the Reagan administration, outraged historians who argue that it conflicts with the mandate of the Presidential Records Act that such papers presumptively be released after twelve years have elapsed.

Even more controversial is a presidential directive issued on November 13, 2001, authorizing military tribunals to try noncitizens suspected of involvement in terrorism. ${ }^{272}$ Asserting "that it is not practicable to apply" normal "principles of law and the rules of evidence" to such cases, the directive specifies that the secretary of defense may determine how to conduct trials before military tribunals that may convict defendants by a two-thirds vote. ${ }^{273}$ The directive expressly prohibits defendants from seeking any legal redress in any federal or state court, or before any international tribunal. This breathtakingly broad assertion of presidential authority, undertaken without consulting Congress, raises extremely serious constitutional questions. ${ }^{274}$ How Congress and the judiciary respond to these assertions of presidential authority will help shape not only the future balance of power between branches of government in our constitutional system, but also the extent of freedom enjoyed by those for whose benefit that system was erected.

270. Exec. Order No. 13,233 § 3(d)(1), (2), 66 Fed. Reg. 56,025, 56,026-27 (Nov. 1, 2001).

271. See, e.g., Richard Reeves, Writing History to Executive Order, N.Y. TimES, Nov. 16, 2001, at A25 (defending the value of open records in recording presidential decisionmaking).

272. Military Order-Detention, Treatment, and Trial of Certain Non-Citizens in the War Against Terrorism, 37 WeEKLY COMP. PRES. Doc. 1665 (Nov. 19, 2001).

273. Id. at 1666 .

274. The directive has provoked harsh criticism from diverse quarters. See, e.g., Harold Hongju Koh, We Have the Right Courts for Bin Laden, N.Y. TIMES, Nov. 23, 2001, at A39 (criticizing President George W. Bush's use of military tribunals and suggesting that trials before civilian courts would deliver fair and swift justice); Robert A. Levy, Don't Shred the Constitution to Fight Terror, WALL ST. J., Nov. 20, 2001, at A18 (asserting that the use of military tribunals represents a likely unconstitutional overreaching by President George W. Bush). 